\title{
Bone diagenesis in a Mycenaean secondary burial (Kastrouli, Greece)
}

\author{
loannis Kontopoulos ${ }^{1}(\mathbb{D}) \cdot$ Kirsty Penkman $^{2} \cdot$ Ioannis Liritzis $^{3} \cdot$ Matthew J. Collins $^{4,5}$
}

Received: 3 November 2018 / Accepted: 6 May 2019 / Published online: 8 June 2019

(C) The Author(s) 2019

\begin{abstract}
This paper presents the characteristics of bone diagenesis in a secondary commingled Mycenaean burial in Kastrouli (Phocis, Greece) through the histological (light microscopy), physical (FTIR-ATR), and biochemical (collagen) analysis of seventeen human (including two petrous bones) and seven animal bones. Post-mortem modifications in bone microstructure, bioapatite, and collagen were characteristic of burial environments with seasonal groundwater and temperature fluctuations. The two human petrous bones displayed a lack of microscopic focal destruction (MFD) sites and a generally good histological preservation, but although a small sample size, did not show any better bioapatite and collagen preservation compared with human femora. Intra-site variations were defined by three main diagenetic patterns that display differences in histological modifications, crystallinity changes, and collagen degradation. These different patterns were either related to different microenvironment conditions and/or influenced by possible differences in the early taphonomic histories experienced by bones prior to secondary deposition. Further, this study highlights the importance of infrared splitting factor (IRSF), carbonate/phosphate ratio (C/P), and general histological index (GHI) for the qualitative assessment of archaeological bone, and the potential use of amide/phosphate ratio (Am/P) as a collagen predictor.
\end{abstract}

Keywords Bone diagenesis $\cdot$ Mycenaean $\cdot$ Secondary burial $\cdot$ Histology $\cdot$ Bioapatite $\cdot$ Collagen

\section{Introduction}

\section{Bone diagenesis}

Bone histology, bioapatite (BAp), and collagen can provide valuable information to the archaeologist and anthropologist.

\section{Highlights}

-Histological, bioapatite and collagen preservation can vary within $30 \mathrm{~cm}$ of sediment.

-Within-site variations may often be related to different funerary treatments. -Human petrous bones show no microscopic focal destruction.

-Alternating cold-wet and warm-dry cycles lead to the complete destruction of bone.

Ioannis Kontopoulos

ik620@york.ac.uk

1 BioArCh, Department of Archaeology, University of York, York, UK

2 BioArCh, Department of Chemistry, University of York, York, UK

3 Laboratory of Archaeometry, Department of Mediterranean Studies, University of the Aegean, Mytilene, Greece

4 Natural History Museum, University of Copenhagen, Copenhagen, Denmark

5 McDonald Institute for Archaeological Research, Department of Archaeology, University of Cambridge, Cambridge, UK
Bone histology can be used for the study of the age-at-death, pathology, distinction between human and non-human or burned and unburned bone, etc. (Stout and Teitelbaum 1976; Cattaneo et al. 1999; Mulhern and Ubelaker 2001; Cuijpers 2006; Hanson and Cain 2007; Dominguez and Crowder 2012; De Boer et al. 2013; Assis et al. 2016). Bioapatite is important in archaeological research for the study of past human and animal mobility (strontium and oxygen isotope analyses), dietary habits (carbon isotope analysis), and environments (oxygen isotope analysis) (Lee-Thorp and van der Merwe 1991; Wright and Schwarcz 1996; Hedges 2003; King et al. 2011). Bone collagen is used to determine chronological age (i.e., ${ }^{14} \mathrm{C}$ dating), past lifeways (e.g., palaeodietary reconstruction, weaning practices), taxonomic identification, and occasionally for screening (e.g., amino acid racemization) (DeNiro and Weiner 1988; Ambrose 1991; Poinar et al. 1996; Collins et al. 1999, 2009; van Klinken 1999; Asara et al. 2007; Buckley et al. 2009; Douka et al. 2017).

The microstructure and the biogenic chemical signals of bone can be altered post-mortem due to bone diagenesis that involves three distinct processes: (a) the microbial attack of bone; (b) the chemical alteration of the inorganic matter (dissolution/recrystallization); and (c) the chemical breakdown of the organic matter (hydrolysis) (Collins et al. 2002; Kendall et al. 2018). Microbial activity can modify bone 
microstructure (Hackett 1981; Bell 1990, 2012; Hedges et al. 1995; Turner-Walker and Jans 2008; Hollund et al. 2012; White and Booth 2014; Kontopoulos et al. 2016) and is manifested by microscopic focal destruction (MFD) sites consisting of foci either rounded (linear longitudinal tunneling), branched (budded and Wedl tunneling), or interlinked (lamellate tunneling) that vary from few microns (linear longitudinal tunneling) to hundreds of microns (i.e., lammellate tunneling) in diameter (Hackett 1981).

Microbial attack can also enzymatically degrade collagen using collagenases, with temperature, $\mathrm{pH}$, hydrology, and time also having a profound effect on collagen degradation (Nielsen-Marsh et al. 2000; Grupe et al. 2002; Collins et al. 2002; Koon et al. 2003, 2010; Kendall et al. 2018). Peptide bond hydrolysis and gelatinization activation energies are very temperature sensitive (Collins and Galley 1998) with collagen loss increasing with increasing temperature (Collins et al. 2002; Kendall et al. 2018). Protein hydrolysis in acidic or alkaline environments can also cause fragmentation to collagen and may allow the more soluble components to be leached out as activation energies are also $\mathrm{pH}$ dependent (Ajie et al. 1991; Collins and Galley 1998). Local hydrology can also play a significant role in the survival of collagen (i.e., soluble fraction) as bones recovered from warm environments (higher thermal age) may have better preserved organic content than samples of similar chronological age recovered from colder environments (lower thermal age), when the local hydrology is more active (van Doorn et al. 2012).

Any collagen preserved in the archaeological bone presumably can be protected by the bioapatite crystals (BAp) (Grupe 1995) due to their strong in vivo relationship (inter-fibrillar and intra-fibrillar deposition of the crystalline material during the mineralization of the organic matrix) (Weiner and Price 1986; Traub et al. 1992; Boskey 2003; Reznikov et al. 2014). The space that is created by the loss of collagen (c. $1 / 3$ of the volume of bone matrix in vivo) can be replaced by the growth of the BAp crystals, as a number of ions usually present in the groundwater (e.g., $\mathrm{HPO}_{4}{ }^{2-}, \mathrm{PO}_{4}{ }^{3-}, \mathrm{CO}_{3}{ }^{2-}, \mathrm{Ca}^{2+}, \mathrm{Mg}^{2+}$ ) can be incorporated into the $\mathrm{BAp}$ crystals to create a more ordered and stable crystal environment (Trueman et al. 2004; Lee-Thorp and van der Merwe 1991; Berna et al. 2004; Stathopoulou et al. 2008; Figueiredo et al. 2012; Trueman 2013; Rey and Combes 2014).

The reorganization of the BAp crystals occurs through recrystallization primarily due to active hydrology (Hedges and Millard 1995; Nielsen-Marsh et al. 2000; Hedges 2002) and/ or when soil pH is slightly alkaline (c. 7.5-8) (Berna et al. 2004), while recrystallization gives way to dissolution in acidic or alkaline environments (Piepenbrink 1989; High et al. 2015). Therefore, identifying the diagenetic history of each bone can offer unique insight into the preservation potential of bone in different burial environments and timescales, which is of great importance to archaeological, anthropological, and forensic research.

\section{The Mycenaean secondary burial in Kastrouli}

The Mycenaean site of Kastrouli (38.40 N, 22.57 E) is a fortified hill situated in the Mesokampos plateau of the Desfina peninsula (Phocis, Greece) at c. $550 \mathrm{~m}$ above sea level, and its position between the Itea and Antikira gulfs was strategic for the control of the entire Desfina peninsula (Fig. 1a). The site has been systematically excavated since 2016, and among the several interesting finds is an undisturbed commingled secondary burial within a rock-cut and built chamber tomb (Sideris et al. 2017). Secondary burials (i.e., the reburial/deposition of the retrieved human skeletal remains, in the same or different locus, at a later time) (e.g., Schroeder 2001) were a common burial practice during the Mycenaean period in Greece. Nonetheless, the forms of secondary treatment (e.g., single secondary burials vs. extensive commingling, tomb elaboration, adult vs. sub-adult individuals) could vary considerably (e.g., Jones 2014; Moutafi and Voutsaki 2016).

The tomb in Kastrouli, which had a W-E orientation, was partly made of limestone and partly carved into the limestone bedrock, and consisted of a dromos in the $\mathrm{W}$, an entrance with monumental lintel, a small chamber, and a niche or extension on the south side covered with a monumental limestone slab (Sideris et al. 2017). The height of the chamber was c. $1.65 \mathrm{~m}$, and although the upper c. $40 \mathrm{~cm}$ of sediment of the tomb was disturbed in antiquity and looted in the past decades, the lower c. $30 \mathrm{~cm}$ layer was undisturbed (Fig. 1b).

This layer was filled with macroscopically poorlypreserved commingled human bones (minimum number of fifteen adult individuals, two subadults, an infant, and a fetus), alongside numerous pottery fragments, few figurines and beads, few small fragments of gold foil, and a small number of domesticated animal bones (e.g., Gallus gallus, Bos taurus, Sus scrofa, Ovis aries/Capra hircus) (Chovalopoulou et al. 2017; Sideris et al. 2017). The bone assemblage was dated on typological grounds of associated ceramic finds to the LH IIIA2-LH IIIC (c. 1350-1150 BC), although a single bone sample (right human femur), residual of the last looting of Tomb A, provided a calibrated ${ }^{14} \mathrm{C}$ age of $810-760 \mathrm{BC}$ (Liritzis et al. 2016). The Late Mycenaean age of the tomb was also confirmed by the OSL dating of the tomb, the fortified wall, and the ceramics (Liritzis et al. 2019).

The macroscopic analysis of commingled skeletal remains is mainly limited to the minimum number of individuals (MNI), sex, approximate age-at-death, stature, pathology, etc. (Osterholtz et al. 2013; Adams and Byrd 2014). Although the application of other techniques (e.g., optical and scanning electron microscopy, ZooMS, DNA) can potentially answer several important archaeological questions (e.g., human vs. non-human bone, species identification, kinship), such analyses can be obstructed through the partially or totally degraded condition of the skeletal remains (Osterholtz et al. 2013; Adams and Byrd 2014). 

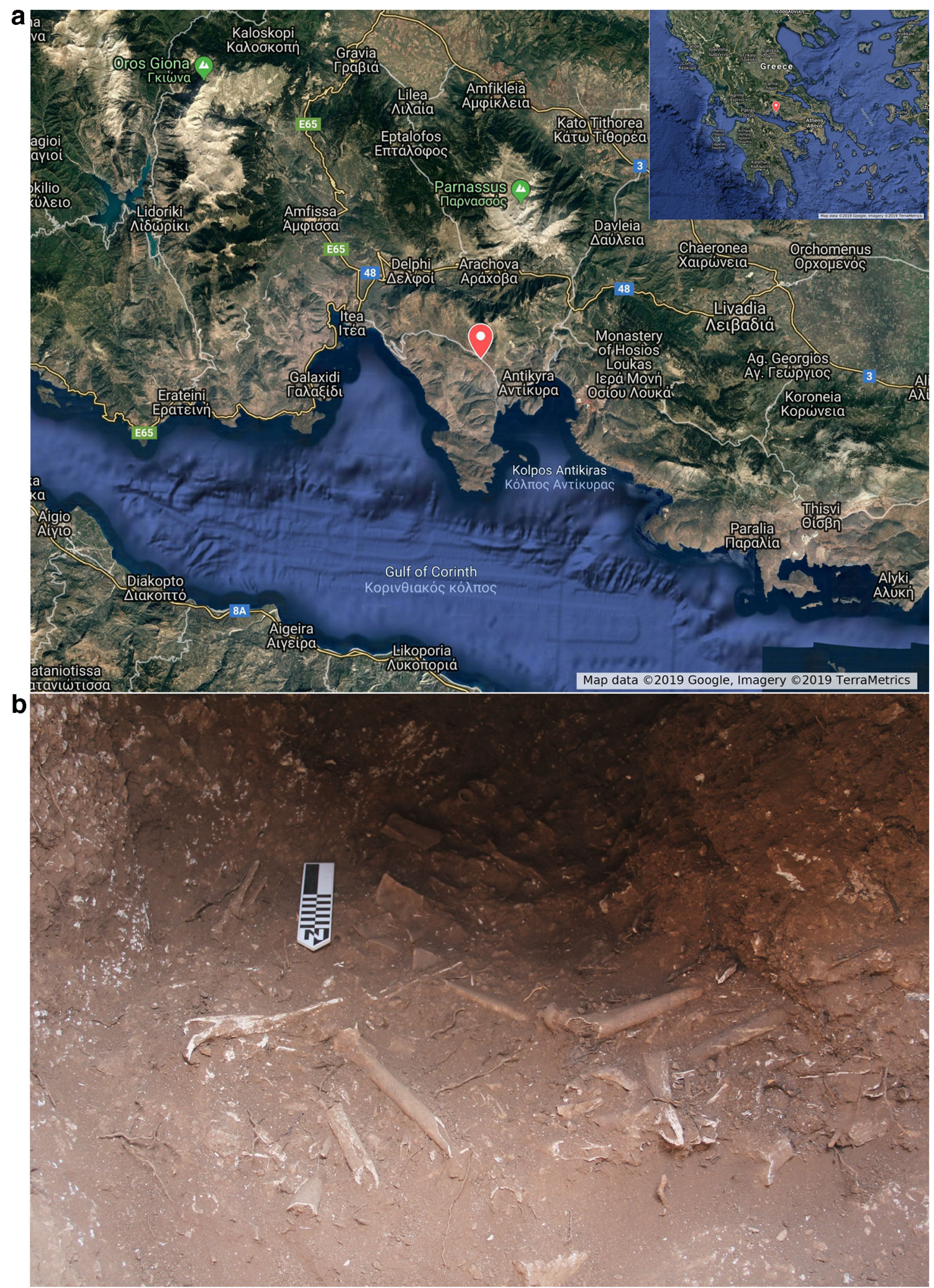

Fig. 1 The strategic position of Kastrouli between the Itea and Antikira Gulfs at the heart of Desfina peninsula (a) and the commingled skeletal remains from tomb A (locus 121) found at c. $1 \mathrm{~m}$ depth (b; scale bar, 1 and $10 \mathrm{~cm}$ )

As only a limited number of studies has ever examined bone diagenesis in commingled, disarticulated secondary burials (e.g., Booth and Madgwick 2016), the aim of this study is to explore the characteristics of bone diagenesis in a secondary 
burial environment. Histological (light microscopy), physical (FTIR-ATR), and biochemical (collagen) analyses of human and animal bones were undertaken in order to explore any differences in the diagenetic changes occurred in those commingled archaeological bones. This multi-analytical approach can help elucidate why and how bone degrades in such conditions and shed light on within-site variations possibly related to different primary and secondary funerary treatments.

\section{Materials and methods}

Fifteen human femora, two human petrous bones, and seven animal bones from the Mycenaean site of Kastrouli, Greece were assessed in this study. IBM SPSS v. 25 was used for the statistical analysis with the significance level set at $p=0.05$. Regression correlation $\left(R^{2}\right)$ is characterized as very weak if it is from 0 to 0.19 , weak from 0.2 to 0.39 , moderate from 0.40 to 0.59 , strong from 0.6 to 0.79 , and very strong correlation from 0.8 to 1 . These are rather arbitrary bounds and should be considered in the context of the results.

\section{Histology}

Twenty-one transverse thin sections from fifteen human femora and six animal bones, and two longitudinal thin sections from two human petrous bones (Table 1) of c. $200 \mu \mathrm{m}$ thickness were prepared using an Exact $300 \mathrm{CL}$ diamond band saw. Entellan New (Merck Chemicals) for microscopy was used to mount the undecalcified thin sections onto glass microscope slides cleaned with xylene before use. Thin sections were assessed under a Leica DM750 optical microscope using plane-polarized (PPL) and cross-polarized (XPL) transmitted light at a total magnification ranging from $\times 40$ to $\times 400$. Digital images were captured by a Leica ICC50 HD camera for microscopy imaging with a capture resolution of $2048 \times$ 1536 pixels. The general histological index (GHI) introduced by Hollund et al. (2012) was used as it is comparable with the Oxford histological index (OHI) as described by Millard (2001) but generalized destruction, cracking, and staining are included in the assessment. A GHI value of five represents excellent microstructural preservation similar to modern bone (>95\% intact microstructure), whereas a GHI value of 0 indicates poor microstructural preservation $(<5 \%$ intact microstructure) with almost no original histological features observed.

\section{FTIR}

FTIR-ATR measurements on fifteen human femora, two human petrous bones, and seven animal specimens (Table 1) were performed in triplicate using a Bruker Alpha Platinum (range: 4000-400 $\mathrm{cm}^{-1}$; No. of scans: 144; zero filling factor: 4; resolution: $4 \mathrm{~cm}^{-1}$; mode: absorbance). A background measurement was run before each sample measurement to reduce the background noise and improve the signal-to-noise ratio (SNR). Sample preparation and analysis was carried out according to Kontopoulos et al. (2018). Bone samples were pulverized using an agate pestle and mortar following the mechanical cleaning of the outer and inner bone surfaces. About 2-3 mg of bone powder of $20-50 \mu \mathrm{m}$ particle size was used for each measurement, and after each measurement, the crystal plate and the anvil of the pressure applicator were thoroughly cleaned using isopropyl alcohol.

The OPUS 7.5 software was used for the calculations of the FTIR indices following: (a) Weiner and Bar-Yosef (1990) for the infrared splitting factor (IRSF $=\frac{600 \mathrm{~cm}^{-1}+560 \mathrm{~cm}^{-1}}{590 \mathrm{~cm}^{-1}}$ ) to assess the BAp crystal size and structural order/disorder, as the larger and/or more ordered crystals display higher IRSF values; (b) Wright and Schwarcz (1996) for the carbonate-to-phosphate $\left(\mathrm{C} / \mathrm{P}=\frac{1410 \mathrm{~cm}^{-1}}{1010 \mathrm{~cm}^{-1}}\right)$ ratio to detect any diagenetic-related changes to the carbonate content of BAp relative to phosphate content; (c) Sponheimer and Lee-Thorp (1999) for the type B carbonate substitutions relative to phosphate $\left(\mathrm{BPI}=\frac{1410 \mathrm{~cm}^{-1}}{600 \mathrm{~cm}^{-1}}\right)$ to detect any diagenetic-related changes to the type $\mathrm{B}$ carbonate environment of BAp relative to phosphate content; and (d) Trueman et al. (2004) for the amide-to-phosphate $\left(\mathrm{Am} / \mathrm{P}=\frac{1640 \mathrm{~cm}^{-1}}{1010 \mathrm{~cm}^{-1}}\right)$ ratio to assess the amount of organic material remaining in the samples relative to phosphate content. The mean values of these indices for two modern human femora and one modern bovine femur were used as reference throughout (Table 1).

For the identification of overlapping/hidden components that cannot be distinguished in the zeroth-order (basic) spectra, derivatization of the spectral curves was carried out (Talsky 1994; Kus et al. 1996; Mark and Workman Jr 2003). The distinction of the overlapping components of the broader amide I band, the $v_{2}$ and the $v_{3} \mathrm{CO}_{3}{ }^{2-}$ bands through $2^{\text {nd }}$ derivative analysis was conducted using the OriginPro 2017 software. The Savitzky-Golay filter was applied to decrease the noise, and a polynomial order of 4 with 13 smoothing points were used for the analysis of the amide I bands and the $v_{2} \mathrm{CO}_{3}{ }^{2-}$ bands (Gander and von Matt 1993; Schafer 2011). As the method is sensitive to noise, a further increase in the number of smoothing points to 25 was applied to the $v_{3}$ $\mathrm{CO}_{3}{ }^{2-}$ band to reduce noise (Kus et al. 1996). Although smoothing reduces the noise, it requires careful consideration as it can also distort the spectral features (Kus et al. 1996).

\section{Collagen}

Collagen was extracted from fifteen human femora, two human petrous bones, and seven animal specimens (Table 1) using a modified Longin (1971) method. The exterior surfaces of the bone samples were mechanically cleaned using a scalpel. Bone chunks of 300-500 mg were demineralized in $8 \mathrm{ml} 0.6 \mathrm{M} \mathrm{HCl}$ at $4{ }^{\circ} \mathrm{C}$. Samples were agitated twice daily and the acid solution 


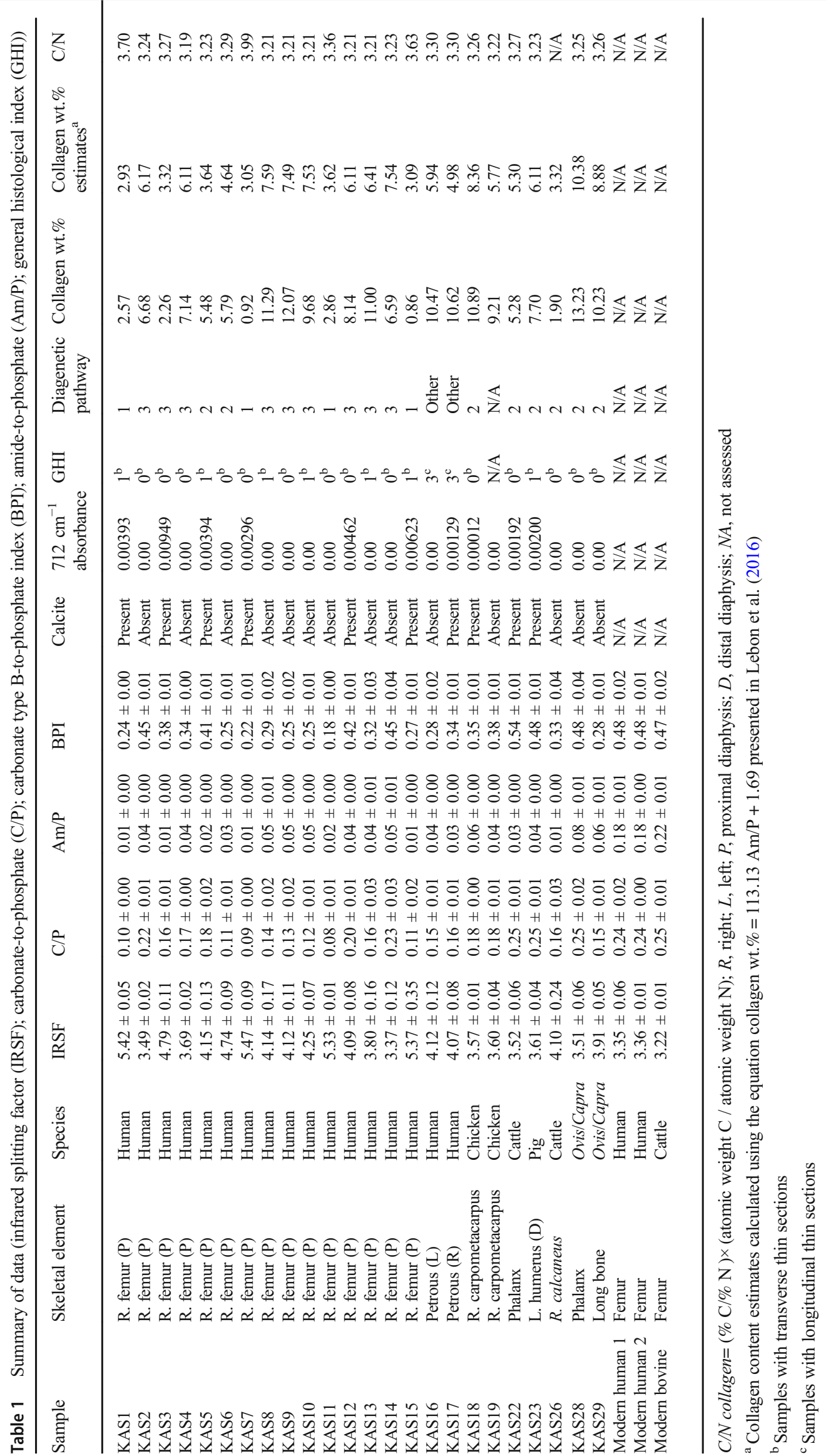


was changed every 2 days. When demineralization was completed, the supernatant was drained off and samples were rinsed $\times 3$ with distilled water. Gelatinization was carried out by adding $8 \mathrm{ml}$ at $\mathrm{pH} 3 \mathrm{HCl}$, and samples were placed in hot blocks at $80^{\circ} \mathrm{C}$ for $48 \mathrm{~h}$. The supernatant which contains the collagen was filtered using Ezee ${ }^{\mathrm{TM}}$ filters and was freeze dried for 2 days in pre-weighed plastic tubes. Collagen yields (wt.\%), which are commonly used to distinguish well-preserved from poorly preserved collagen were estimated using the formula: bone mass $(\mathrm{mg}) /$ collagen mass $(\mathrm{mg}) \times 100$, where bone mass is the weight of bone chunks after cleaning the exterior surfaces, and collagen mass is the extracted material that remains following demineralization, gelatinization, and filtering.

The extracted collagen was analyzed in duplicate using a Sercon 20-22 mass spectrometer at the University of York (BioArCh) and following standard procedures. Thirty-six tin capsules containing $0.9-1.1 \mathrm{mg}$ of collagen were dropped into an oxygen-rich combustion tube held at $1000^{\circ} \mathrm{C}$, while fifteen tin capsules of Bradford fish gel standard, three tin capsules of IA CANE (cane sugar), three tin capsules of IAEA 600 (caffeine), three tin capsules of IAEA N2 (ammonium sulfate), and three tin capsules of modern bovine collagen, all containing $0.9-1.1 \mathrm{mg}$ of material, were used as standards. The tin capsules were ignited and burnt exothermally at $1800^{\circ} \mathrm{C}$ causing the sample to oxidize.

The samples were carried through a layer of chromium oxide, and copper oxide which ensure complete oxidation, followed by a layer of silver wool to remove unwanted sulfur and halides. The sample gases then passed into a second furnace containing copper held at $600{ }^{\circ} \mathrm{C}$ where excess oxygen was removed and nitrogen oxides were reduced to elemental nitrogen. Any water was removed using a magnesium perchlorate trap. The samples then passed into a gas chromatography (GC) column held at $70{ }^{\circ} \mathrm{C}$, which separates $\mathrm{CO}_{2}$ and $\mathrm{N}_{2}$ from each other. The resultant gases were then introduced into the mass spectrometer where the samples were ionized, and the various masses were separated in a magnetic field, focused into Faraday collector arrays and analyzed.

\section{Results and discussion}

\section{Histological preservation}

Histological preservation is very poor in Kastrouli (Table 1) with three distinct pathways identified based on the presence/ absence of microscopic focal destruction (MFD), microcracking, and orange/brown staining (Fig. 2). All human femora and animal bones appear microstructurally amorphous with histology often displaying disintegration, although some limited morphological features may still be recognizable. Generalized destruction (Fig. 3a) is accompanied by a loss of birefringence in the amorphous areas under cross polarized light, linked to a loss of collagen (Piepenbrink 1986; Garland 1989; Collins et al. 2002; Caruso et al. 2018). The two human petrous bones also have many amorphous, disintegrated areas of bone (Fig. 3b) accompanied by a loss of collagen birefringence, although the latter is still retained in many areas across the petrous thin sections. The endosteal tissue that surrounds the cochlea and semicircular canal areas is considered more mineralized (Doden and Halves 1984; Katić et al. 1991; Frisch et al. 2000; Jeffery and Spoor 2004), however, it is unexpectedly more degraded than the periosteal tissue.

Microscopic focal destruction (MFD) is present in nine human femora, while the two human petrous bones and all animal bones show no signs of bacterial attack (Table 1). Possible microbial activity in the two human petrous bones appears as merged osteocyte lacunae; however, these are very sparse (Fig. 3b). MFD in human femora appear as linear longitudinal (oval-shaped) and budded tunnels separated by hypermineralized tissue (or cuffing) (Fig. 4a). Cuffing displays a dark coloration (brown/black) in plane polarized light (Fig. 4a) and it appears denser than the unaffected areas (Hackett 1981; Piepenbrink 1989; Bell 1990). It is believed that it forms by mineral redeposition and waste products when microbes remove the inorganic matrix to attack collagen (Hackett 1981; Garland 1989; Jackes et al. 2001; Hedges 2002; Fernandez-Jalvo et al. 2010), which explains why it has higher concentrations of $\mathrm{Ca}$ and $\mathrm{P}$ compared with the unaffected bone (Pesquero et al. 2015). This hypermineralized tissue is a few micrometers in size, mostly surrounding the smaller non-Wedl MFD (Fig. 4a), and it inhibits further expansion of the MFD (Hackett 1981; Piepenbrink 1986). The "mosaic pattern" observed in Fig. $4 \mathrm{~b}$ is also considered to be the final stage of bacterial attack, removing almost all microstructural features (Hackett 1981; Piepenbrink 1986; TurnerWalker and Jans 2008).

Groundwater fluctuation in Kastrouli (Fig. 5) due to hot and dry summers (desiccation, which causes the bone to shrink) followed by cold and humid winters (water uptake that swells bone collagen) has played a key role in altering bone and has resulted in the poor histological preservation (Hackett 1981; Hedges and Millard 1995; Nielsen-Marsh and Hedges 2000a; Turner-Walker 2008; Turner-Walker and Jans 2008; Pfretzschner and Tütken 2011). Desiccation is evidenced by microcracks (Pfretzschner and Tütken 2011) observed centrally (Fig. 4a; spread from the Haversian canal outwards), peripherally (Fig. 4a; spread from the cement line inwards), circumferentially, and interstitially (Fig. 4c; run across circumferential and interstitial lamellae) in several bones. Additionally, the wet and dry (oxygen-rich environment) cycles in Kastrouli also favor the survival and activity of microorganisms in bone (Hackett 1981; Reiche et al. 2003; TurnerWalker and Jans 2008), while microcracking would further accelerate protein degradation and mineral transformation by increasing the flow of groundwater through the bone. 
Fig. 2 The three different diagenetic pathways histologically identified in Kastrouli bones (see also Table 1)
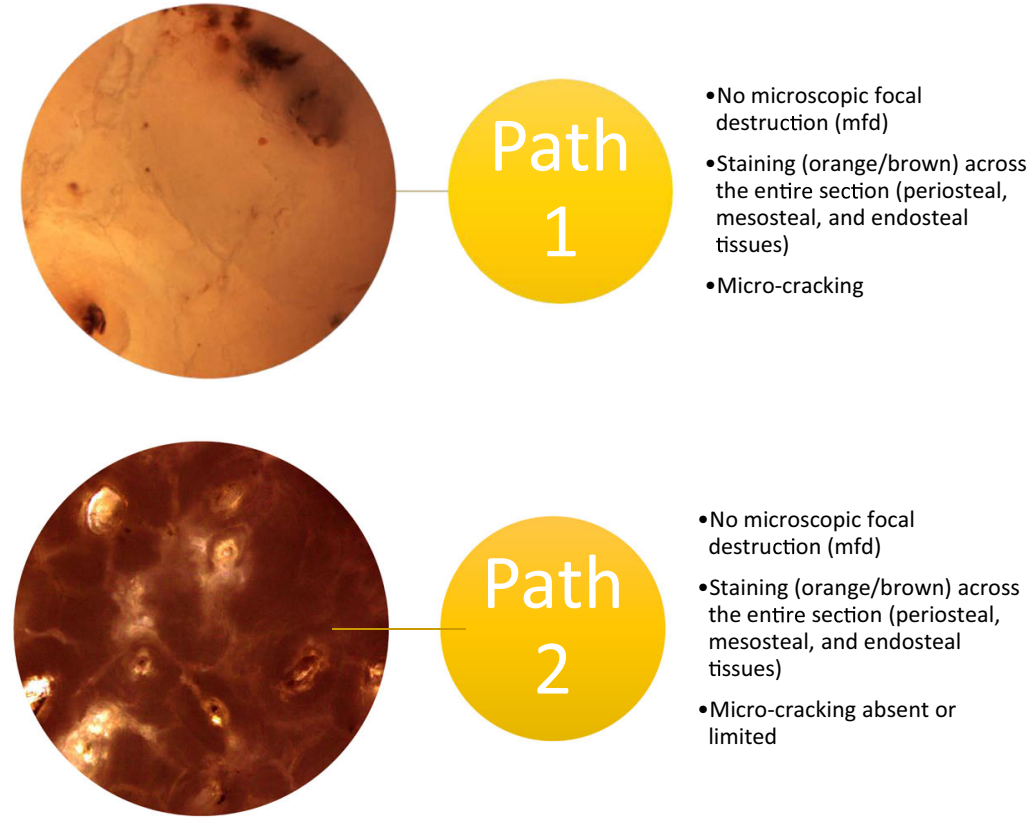

- No microscopic focal destruction (mfd)

- Staining (orange/brown) across the entire section (periosteal, mesosteal, and endosteal tissues)

- Micro-cracking absent or limited

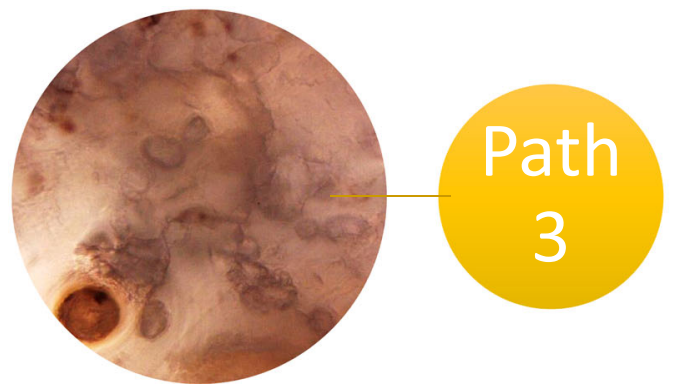

-Microscopic focal destruction $(\mathrm{mfd})$ in endosteal and mesosteal tissues

- Staining (orange/brown) mainly of periosteal tissues

-Micro-cracking

\section{Bioapatite preservation}

Dissolution/recrystallization of BAp crystals in Kastrouli is indicated by the histological appearance of many samples (e.g., microcracking, loss of birefringence). A combination of flow and recharge hydrological environments (Hedges and Millard 1995; Nielsen-Marsh et al. 2000) has clearly affected bioapatite preservation at this site. The seasonal or sporadic (wet and dry cycles; Fig. 5) flow of undersaturated (with respect to BAp) rainwater (Grupe 1995; Hedges and Millard 1995; Nielsen-Marsh et al. 2000) through the bones situated near the ground surface (depth c. $1 \mathrm{~m}$ ) has led to the recrystallization of bioapatite crystals.

The IRSF values range from 3.37 to 5.47 (mean $=4.38 \pm$ 0.69 ) in human bones and from 3.51 to 4.10 (mean $=3.69 \pm$ 0.23 ) in animal bones. These crystallinity values are higher than the modern human bone references' mean IRSF value (i.e., $3.36 \pm 0.01$; Fig. 6a) and indicate an expansion of the crystal dimensions. This increase may be due to Ostwald ripening (larger crystals absorb the smaller ones), loss of the smaller crystals through dissolution, or both (Weiner and
Bar-Yosef 1990; Stiner et al. 1995; Wright and Schwarcz 1996; Nielsen-Marsh and Hedges 2000b; Nielsen-Marsh et al. 2000; Reiche et al. 2002; Trueman 2013). To assess whether the distribution (mean ranks) of crystallinity (IRSF) values between the human $(n=17$; including the two petrous bones) and animal $(n=7)$ bones is different, a Mann-Whitney $\mathrm{U}$ test was used as the IRSF values were not normally distributed in the latter group (Shapiro-Wilk: $p=0.031$ ). The statistical analysis indicated that the human bones (mean rank= $14.82)$ tend to have higher crystallinity values than the animal bones (mean rank 6.86) $(U=20.000, p=0.011)$.

Regarding the carbonate content, $\mathrm{C} / \mathrm{P}$ ranges from 0.23 to 0.08 (mean $=0.15 \pm 0.05$ ) in human bones, and from 0.25 to 0.15 (mean $=0.20 \pm 0.05$ ) in animal bones. Similarly, as normality was not met in the animal bones (Shapiro-Wilk: $p=$ 0.042), a Mann-Whitney $U$ test indicated that the animal bones (mean rank $=17.86$ ) have higher $\mathrm{C} / \mathrm{P}$ values than the human bones (mean rank $=10.29)$ in Kastrouli $(U=22.000, p=$ 0.016). A loss of $\mathrm{CO}_{3}{ }^{2-}$ content during dissolution/ recrystallization is thus observed in our samples compared with modern samples (Fig. 6a). The human bones display an average 

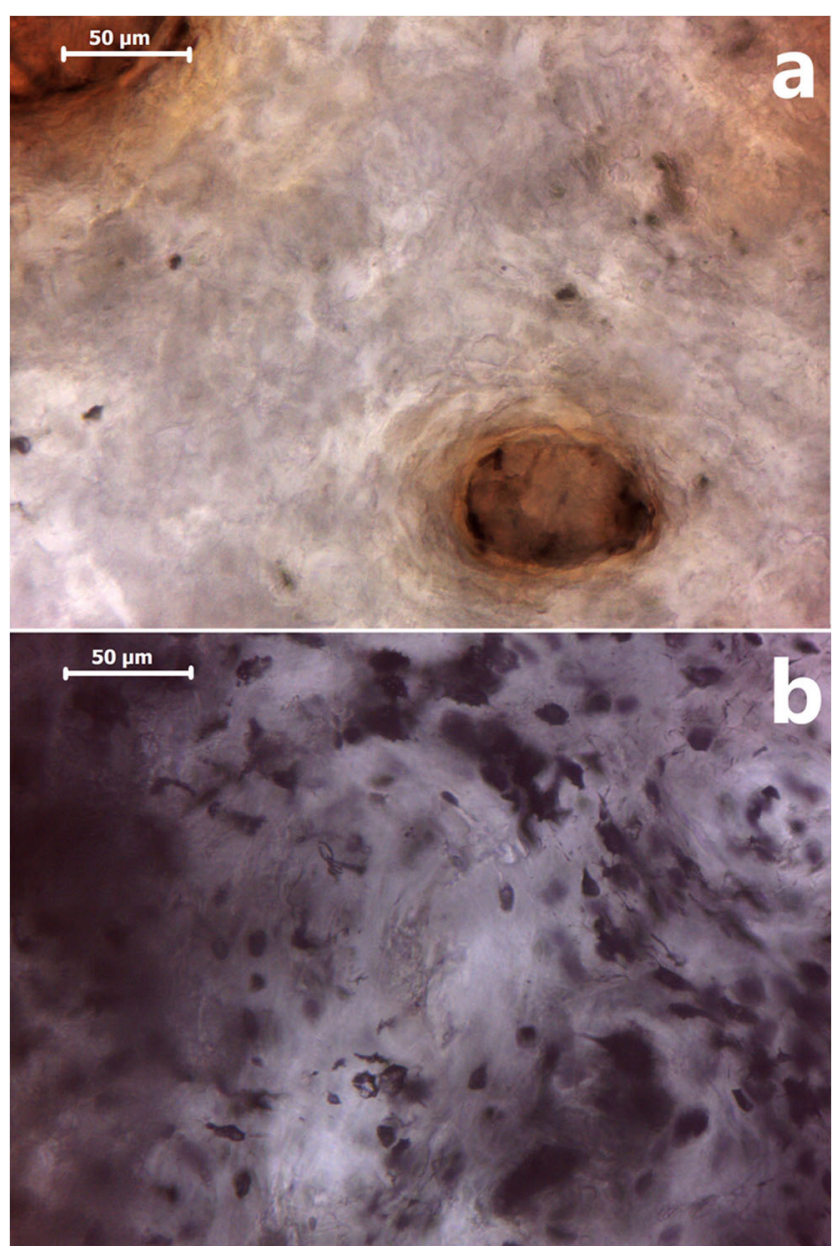

Fig. 3 a KAS2 transverse PPL $\times 400$ - human femur: no histological features can be recognized, accompanied by a complete loss of birefringence (hence no image). b KAS16 longitudinal PPL $\times 400-$ human petrous bone: osteocyte lacunae still preserved. Note the few merged lacunae which can be an indication of limited microbial activity.

loss of about $40 \%$ of the initial carbonate and the animal bones of about $20 \%$ of their initial $\mathrm{CO}_{3}{ }^{2-}$, although the average crystal size and atomic disorder vary between animal species and hard tissues (Asscher et al. 2011).

The IRSF and the C/P ratios display a very strong inverse correlation for the human bones $\left(R^{2}=0.87\right)$ and a strong inverse correlation for the animal bones $\left(R^{2}=0.61\right)$. This indicates that while recrystallization in bones results in a loss of carbonate from the bioapatite crystals, this loss of $\mathrm{CO}_{3}{ }^{2-}$ can vary within the same site and between different species (Fig. $6 \mathrm{a}, \mathrm{b})$. There are also statistically significant differences in crystallinity $(F(2)=22.260, p=0.000)$ and $\mathrm{C} / \mathrm{P}(F(2)=$ $6.989, p=0.006$ ) between the three different diagenetic pathways described at the site. The use of the one-way ANOVA test indicated that the diagenetic pathway $1(n=4)$ displays the poorest inorganic preservation with very high crystallinity values $(\mathrm{IRSF}=5.4 \pm 0.06)$ and very low carbonate content $(\mathrm{C} / \mathrm{P}=0.09 \pm 0.01)$ which is statistically significant different compared with the other two diagenetic pathways (IRSF:
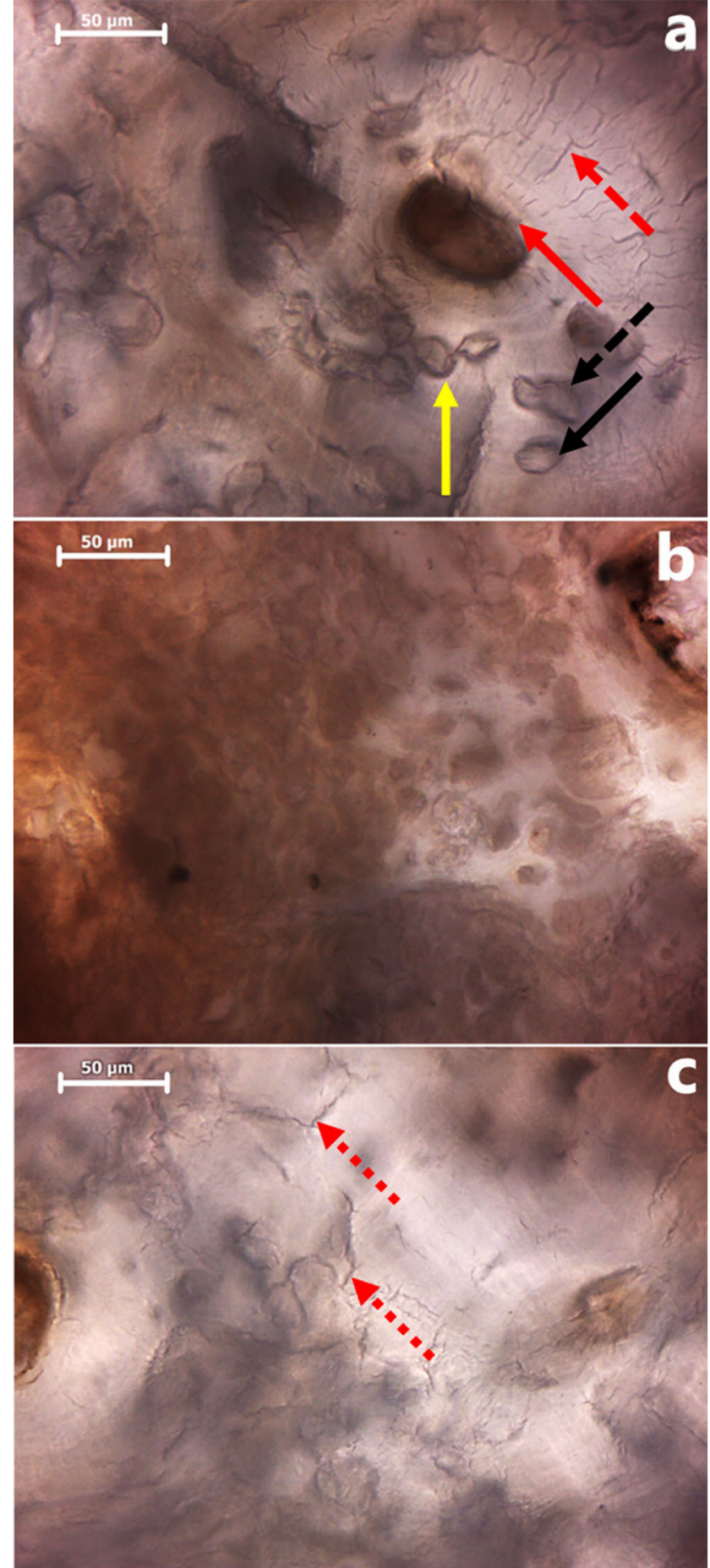

Fig. 4 a KAS9 transverse PPL $\times 400$ human femur: MFD in the form of linear-longitudinal (black arrow) and budded (dashed black arrow) tunnels surrounded by hypermineralized tissue (yellow arrow). Note the central (red arrow) and peripheral (dashed red arrows) microcracks. b KAS13 transverse PPL $\times 400$ - human femur: the characteristic "mosaic pattern" attributed to extensive bacterial activity. $\mathbf{c}$ KAS1 transverse PPL $\times 400$ - human femur: microcracking in degraded interstitial lamellae (dotted red arrows).

diagenetic pathway 1 vs. pathway $2, p=0.000$; IRSF: diagenetic pathway 1 vs. pathway $3, p=0.000 ; \mathrm{C} / \mathrm{P}$ : diagenetic 


\section{CLIMATOLOGICALDATA}

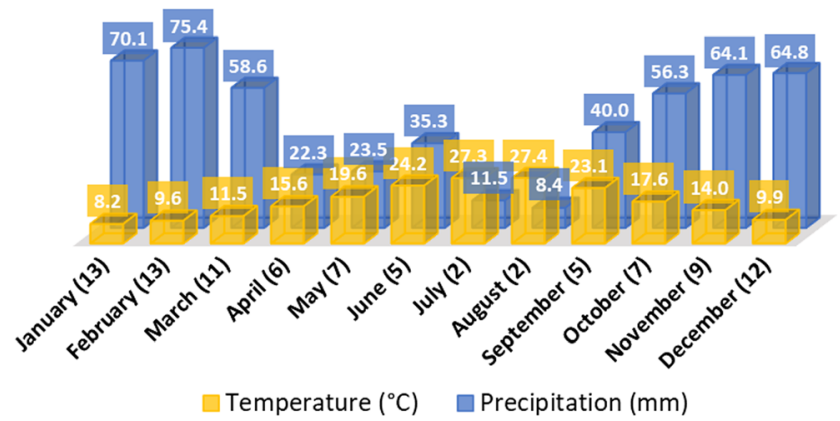

Fig. 5 Mean monthly temperatures $\left({ }^{\circ} \mathrm{C}\right)$ and precipitation $(\mathrm{mm})$ from January 2010 to January 2019 measured at the nearby Antikira weather station ( $38^{\circ} 24^{\prime} \mathrm{N} 22^{\circ} 36^{\prime}$; elevation, $336 \mathrm{~m}$ ). The measurements were made on a continuous basis every $10 \mathrm{~min}$ from 01.01 .2010 to 31.01 .2019 . The average days of precipitation for each month over this 9-year period is provided in parenthesis. The climatological data are available through the National Observatory of Athens, Greece (see Moustris and Petrou 2019)

pathway 1 vs. pathway $2, p=0.004 ; \mathrm{C} / \mathrm{P}$ : diagenetic pathway 1 vs. pathway $3, p=0.023)$. The diagenetic pathway $3(n=9)$ shows intermediate values with lower crystallinity $(\mathrm{IRSF}=$ $3.97 \pm 0.44)$ and slightly higher $\mathrm{CO}_{3}{ }^{2-}$ values $(\mathrm{C} / \mathrm{P}=0.12 \pm$ $0.04)$, and compared with the diagenetic pathway $2(n=8)$ that demonstrates the best BAp preservation with IRSF $=3.89 \pm$ 0.43 and $\mathrm{C} / \mathrm{P}=0.19 \pm 0.05$, there is no statistically significant difference (IRSF $p=0.904 ; \mathrm{C} / \mathrm{P} p=0.569$ ).

Carbonate ions (4-6 wt.\%) can be exchanged with $\mathrm{OH}^{-}$ (type A) or $\mathrm{PO}_{4}{ }^{3-}$ (type $\mathrm{B}$ ) ions in the bioapatite crystal lattice (LeGeros 1965; Wopenka and Pasteris 2005). Type A substitutions require $900-1000{ }^{\circ} \mathrm{C}$, hence no water, while type $\mathrm{B}$ substitutions are the dominant substitutions in bone as they occur at $25-100{ }^{\circ} \mathrm{C}$ (LeGeros 1965). The very strong linear relationship $\left(R^{2}=0.85\right.$; Fig. $\left.6 \mathrm{c}, \mathrm{d}\right)$ between the c. $1410 \mathrm{~cm}^{-1}$ peak and the c. $872 \mathrm{~cm}^{-1}$ peak that is also assigned to type B carbonate (Elliott 1964; LeGeros et al. 1969; Rey et al. 1989) shows that $\mathrm{C} / \mathrm{P}\left(1410 \mathrm{~cm}^{-1} /\right.$ $1035 \mathrm{~cm}^{-1}$ ) predominantly reflects the type $\mathrm{B} \mathrm{CO}_{3}{ }^{2-}$ environment (Sponheimer and Lee-Thorp 1999). A substitution of $\mathrm{CO}_{3}{ }^{2-}$ by $\mathrm{PO}_{4}{ }^{3-}$ during recrystallization increases the unit cell dimensions of BAp crystals, as $\mathrm{PO}_{4}{ }^{3-} \mathrm{O}-\mathrm{O}$ distances are longer than these in $\mathrm{CO}_{3}{ }^{2-}$ (LeGeros et al. 1969), while it also results to more ordered crystal lattices (LeGeros 1965; LeGeros et al. 1967; Wopenka and Pasteris 2005; Rey et al. 2007). When crystallinity (IRSF) is plotted against type $\mathrm{B} \mathrm{CO}_{3}{ }^{2-}$ (BPI); however, it appears that the exchange of ions at the type $\mathrm{B} \mathrm{CO}_{3}{ }^{2-}$ site has less impact on BAp crystals of animal bones than in humans (Fig. $6 \mathrm{e}, \mathrm{f}$ ), which implies differences in the diagenetic pathways followed by human and animal bones in Kastrouli.

Calcite $\left(\mathrm{CaCO}_{3}\right)$ is identified in ten samples (Table 1) primarily by the presence of a peak at $712 \mathrm{~cm}^{-1}\left(v_{4}\right.$ carbon-oxygen inplane bending) (Hunt et al. 1950; Baxter et al. 1966), while changes in the absorbance heights of the $872 \mathrm{~cm}^{-1} \nu_{2}$ carbon- oxygen out-of-plane bending and the $1410 \mathrm{~cm}^{-1} \nu_{3}$ carbonoxygen asymmetric stretching (Elliott 1964; Baxter et al. 1966; LeGeros et al. 1969; White 1974) have also provided useful information. The strong linear relationship $\left(R^{2}=0.71\right)$ between the $v_{4}\left(712 \mathrm{~cm}^{-1}\right)$ and the $\nu_{2}\left(872 \mathrm{~cm}^{-1}\right)$ vibration modes in our samples compared with the weak correlation $\left(R^{2}=0.2\right)$ between the $\nu_{3}\left(1410 \mathrm{~cm}^{-1}\right)$ and the $v_{4}\left(712 \mathrm{~cm}^{-1}\right)$ suggests that the former modes are more sensitive indicators of calcite in archaeological bone. The $712 \mathrm{~cm}^{-1}$ is considered characteristic of the changes in the $\mathrm{Ca}-\mathrm{O}$ distance during vibration which is three times larger for the $v_{4}$ mode compared with the $\nu_{2}$ mode (Gueta et al. 2007).

The carbonate moieties are coplanar and the $\mathrm{O}_{1}-\mathrm{O}_{2}$ distance affects the in-plane bending vibration $\left(v_{4}\right.$ mode) more than the out-of-plane bending vibration ( $\nu_{2}$ mode) (Gueta et al. 2007). This is important for the distinction between a rather amorphous bone calcium carbonate (lower order with greater $\mathrm{Ca}-\mathrm{O}$ and $\mathrm{O}_{1}-\mathrm{O}_{2}$ distances) and exogenous calcite (higher order with smaller distances) (Gueta et al. 2007). The mean IRSF $=4.41 \pm 0.79$ and $\mathrm{C} / \mathrm{P}=0.17 \pm 0.06$ for samples displaying calcite uptake compared with IRSF $=4.01 \pm 0.53$ and $\mathrm{C} / \mathrm{P}=0.16 \pm 0.05$ in samples without calcite demonstrates how the calcite uptake increases BAp crystal order (increased IRSF).

The $\nu_{2}$ carbonate band at c. $850-900 \mathrm{~cm}^{-1}$ which is considered free of organic constituents (Termine et al. 1973) and generally free of $\mathrm{HPO}_{4}{ }^{2-}$ artifacts (Rey et al. 1989) also offers useful information through $2^{\text {nd }}$ derivative analysis (Fig. 7). The two main carbonate bands in modern bone at c. 879 and c. $871 \mathrm{~cm}^{-1}$, which appear slightly shifted in archaeological bone, are frequently assigned to type A (stuffed, i.e., located in the crystal channel and oriented with two oxygen atoms close to the $c$-axis) and type B (positioned close to the sloping faces of the phosphate tetrahedron) carbonates, respectively (LeGeros 1965; LeGeros et al. 1967; Rey et al. 1989; Fleet and Liu 2004, 2005; Fleet et al. 2004; Fleet 2009). A gradual increase in the $871 \mathrm{~cm}^{-1}$ component is observed that is accompanied by a loss of the $879 \mathrm{~cm}^{-1}$ component with increasing calcite content $\left(712 \mathrm{~cm}^{-1}\right.$ absorbance height) in bones from Kastrouli (Fig. 7) that is not reflected in C/P values likely due to small variations of the lattice dimensions of the substituents (Rey et al. 1989).

Therefore, the $2^{\text {nd }}$ derivative analysis of the $\nu_{2} \mathrm{CO}_{3}{ }^{2-}$ mode potentially indicates that an uptake of calcite (or its formation from dissolved carbonate ions and free calcium ions present in water (Fernández-Jalvo et al. 2016)) may occur at the sloping faces of BAp crystals, replacing type $\mathrm{B} \mathrm{CO}_{3}{ }^{2-}$ during the interaction of bone with groundwater in the burial environment (Wright and Schwarcz 1996; Maurer et al. 2014). This uptake of calcite from the burial environment may be either accompanied by a gradual loss of the type A carbonate (disappearance of the $879 \mathrm{~cm}^{-1}$ component, i.e., complete 

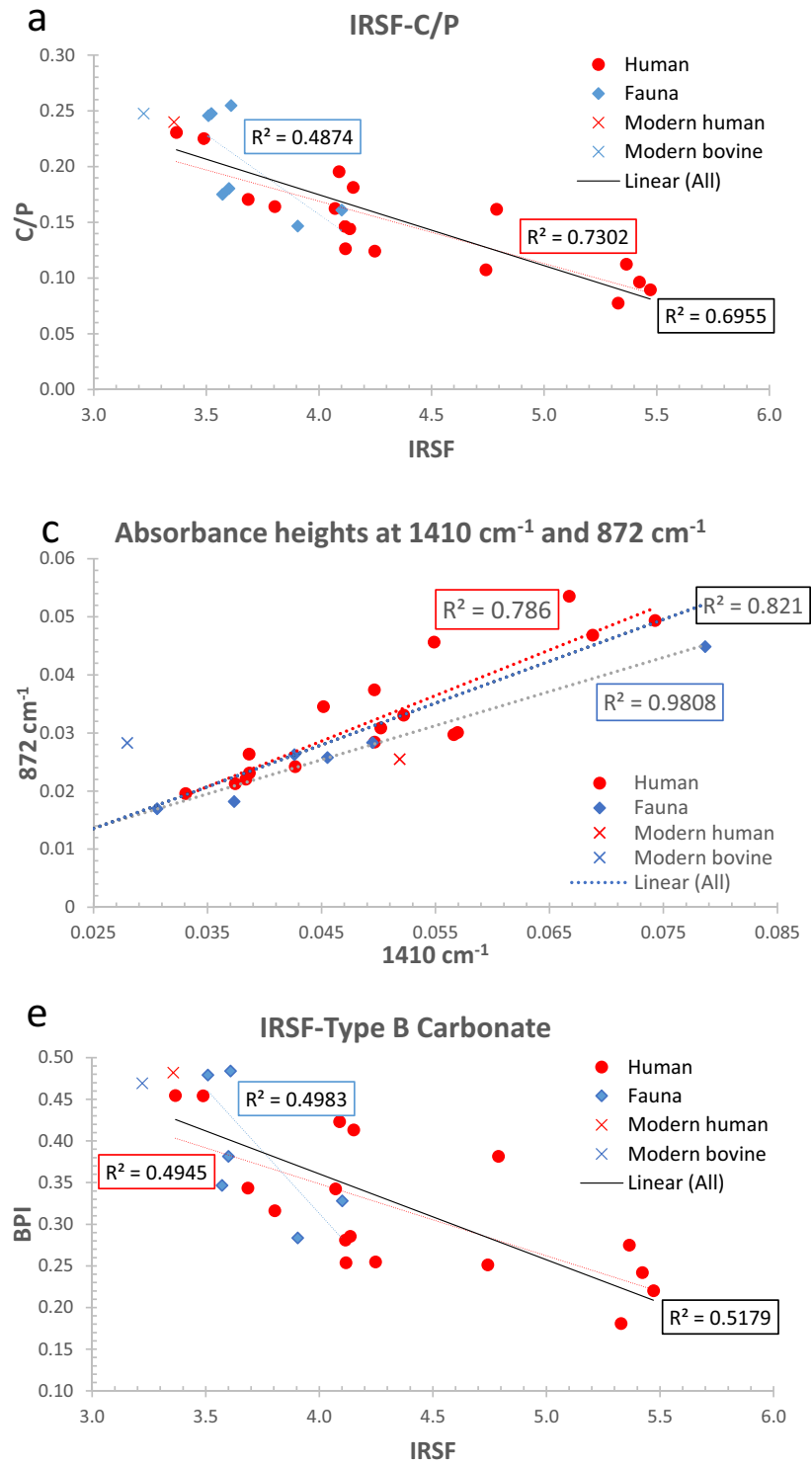

Fig. 6 a The relationship between crystallinity (IRSF) and carbonate content $(\mathrm{C} / \mathrm{P})$ in BAp crystals. b Same as (a), excluding samples containing calcite. c Correlation between 1410 and $872 \mathrm{~cm}^{-1}$ showing that type $\mathrm{B}$ carbonate is the main $\mathrm{CO}_{3}{ }^{2-}$ type reflected in $\mathrm{C} / \mathrm{P}$ values. $\mathbf{d}$ Same as (c),

transformation of BAp) during severe dissolution of the crystal, and/or the exogenous carbonate/calcite vibrations mask the c. $879 \mathrm{~cm}^{-1}$ component (i.e., partial transformation of BAp). As the $\mathrm{CO}_{3}{ }^{2-}$ for $\mathrm{OH}^{-}$substitution is achieved only with the exclusion of water, it is difficult for type A substitution to occur in bioapatite (LeGeros et al. 1969).

Finally, the presence of the c. $866 \mathrm{~cm}^{-1}$ component which has been observed in modern bone and it has been linked to non-apatitic (labile) carbonate environment in amorphous calcium carbonate (Elliott 1964; Rey et al. 1989) is not observed in the $2^{\text {nd }}$ derivative spectra of the Kastrouli bones (Fig. 7). Its absence from archaeological bone has been reported in previous studies (Kontopoulos et al. 2018), although contrary to this data, Stathopoulou et al. (2008) observed the $866 \mathrm{~cm}^{-1}$
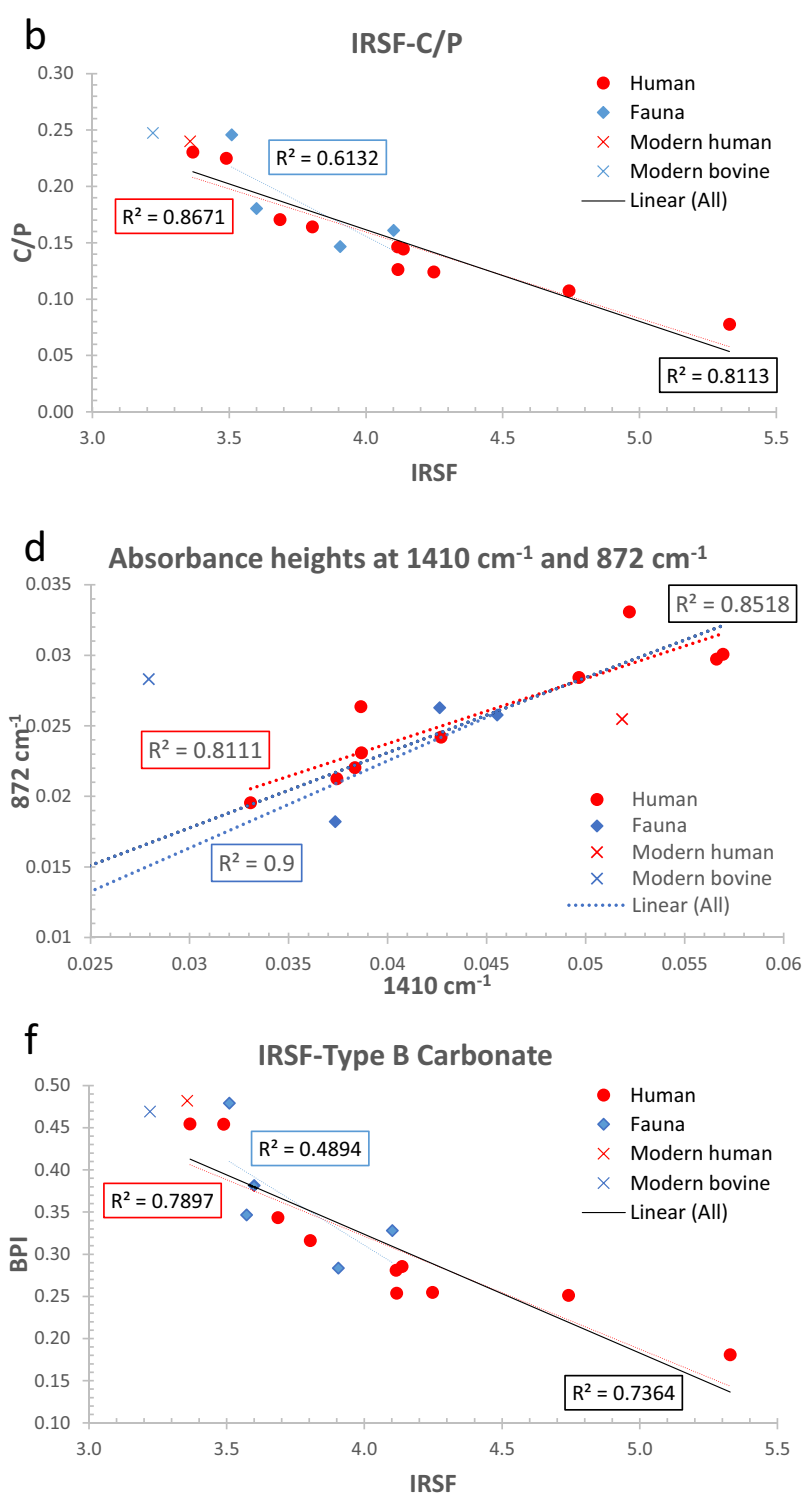

excluding samples containing calcite. e The relationship between crystallinity (IRSF) and type $\mathrm{B} \mathrm{CO}_{3}{ }^{2-}$. f Same as (e), excluding samples containing calcite

component in fossilized bones and it increases with increasing crystallinity.

The spectra in the $\nu_{3}$ carbon-oxygen asymmetric stretching mode (c. $1400-1600 \mathrm{~cm}^{-1}$ ) are very complex (Fig. 8). The $2^{\text {nd }}$ derivative analysis of this domain shows that almost all the components decrease to different extents in archaeological bone compared with modern bone, except for the $1451 \mathrm{~cm}^{-1}$, the $1501 \mathrm{~cm}^{-1}$, and the $1517 \mathrm{~cm}^{-1}$ peaks that remain relatively unchanged (Fig. 8a, b). However, the archaeological bone with calcite uptake shows different characteristics (Fig. 8c). Specifically, there is an increase in the slightly shifted 1411 $\mathrm{cm}^{-1}$ component, and a small increase in the $1468 \mathrm{~cm}^{-1}$ and $1551 \mathrm{~cm}^{-1}$ peaks (Fig. 8c) compared with the archaeological bone without calcite (Fig. 8b). These changes are accompanied 

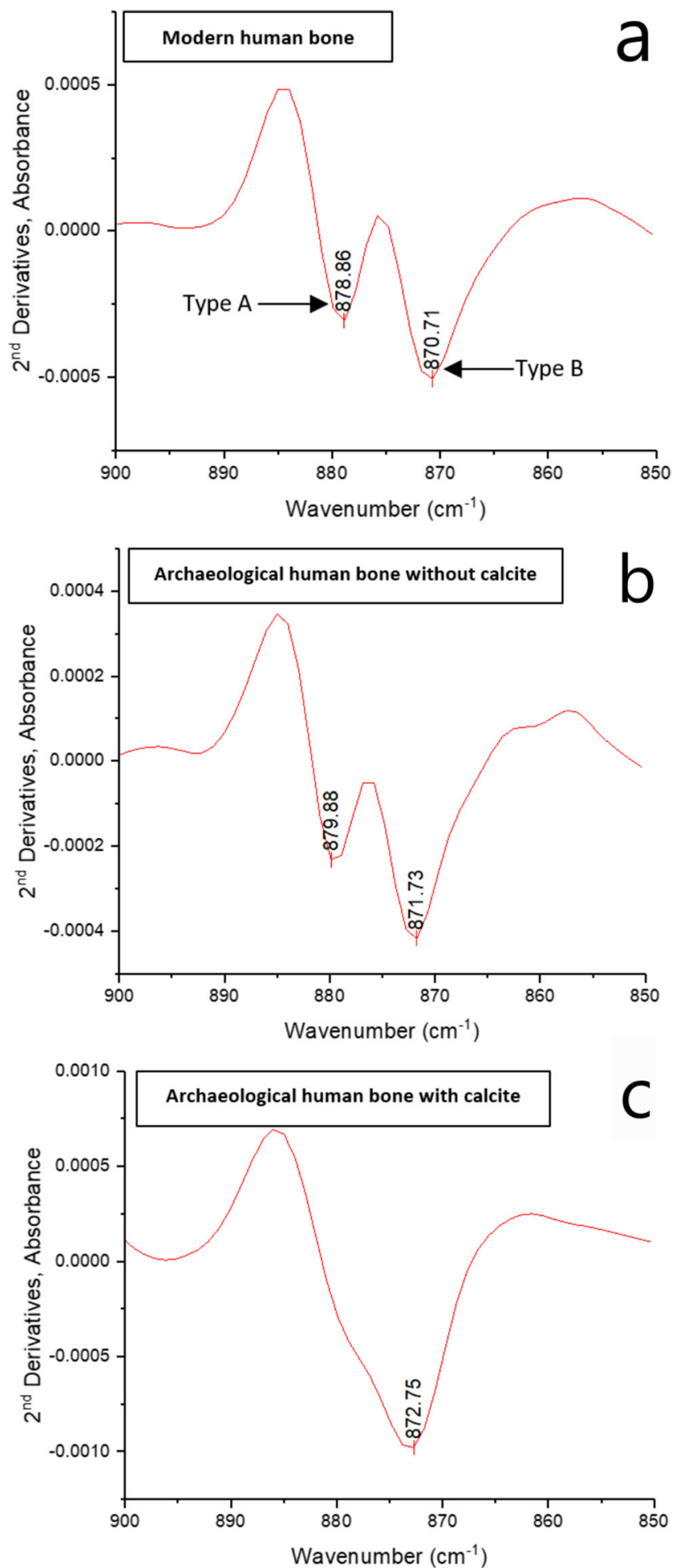

Fig. 7 Second derivative spectra of the $\nu_{2}$ carbonate band at c. 850 $900 \mathrm{~cm}^{-1}$ of modern human bone (a) and two archaeological human bones with $\mathrm{C} / \mathrm{P}=0.16$ but different calcite amounts (b KAS13; c KAS3). Note the effect on the $879 \mathrm{~cm}^{-1}$ component when there is an uptake of calcite (b vs. c)

by a decrease in the $1535 \mathrm{~cm}^{-1}$ and $1568 \mathrm{~cm}^{-1}$ components, whereas the remaining peaks appear unchanged (Fig. 8c).
A decrease in the $1468 \mathrm{~cm}^{-1}$ and $1536 \mathrm{~cm}^{-1}$ peaks can be possibly related to loss of type $\mathrm{A} \mathrm{CO}_{3}{ }^{2-}$ (Rey et al. 1989; Madupalli et al. 2017), while a decrease in the $1411 \mathrm{~cm}^{-1}$ peak in the archaeological bone without calcite uptake can be linked to a loss of type B structural carbonate (Rey et al. 1989; Fleet and Liu 2004). This is also reflected in the decreased, compared with modern bone, C/P ratio of KAS13. On the other hand, an increase in the $1411 \mathrm{~cm}^{-1}$ peak in the specimen with calcite uptake possibly indicates the position that calcite predominantly occupies in BAp crystals (i.e., type B). Lastly, a decrease of the $1536 \mathrm{~cm}^{-1}$ and $1552 \mathrm{~cm}^{-1}$ components (Fig. 8) may also be attributed to a loss of organic content (amide II) (Paschalis et al. 2001; Chadefaux et al. 2009).

Combined, it seems that there is a loss of some A site components both in the $\nu_{3}$ and the $\nu_{2}$ modes and a coprecipitation of exogenous carbonate and phosphate in $\mathrm{B}$ sites. An A site carbonation in the apatitic $c$-axis channel would require much higher energy than $B$ site carbonation of phosphate sites (Madupalli et al. 2017); thus a loss of type A carbonate during partial BAp crystal dissolution, followed by recrystallization and incorporation of exogenous $\mathrm{CO}_{3}{ }^{2-}$, is more probable. Additionally, exogenous carbonate may be positioned differently and these changes observed in the $2^{\text {nd }}$ derivative components could be caused by the changes in carbonate orientation (Madupalli et al. 2017). It is also likely that the hypothesis of two carbonate environments, each of which has its own characteristic absorption spectrum, might be an oversimplification, while the allocation of specific derivative peaks to each $\mathrm{CO}_{3}{ }^{2-}$ type requires further exploration (Elliott 1964; Elliott et al. 1985).

It is difficult to make any safe assumptions on the location of exogenous $\mathrm{CO}_{3}{ }^{2-}$ in the BAp crystal lattice due to the extensive overlapping and a variation in peak positions for the carbonate ion (Fleet and Liu 2004). The many bands and shoulders displayed in these regions are still not safely assigned to a specific $\mathrm{CO}_{3}{ }^{2-}$ site (Elliott 1964; LeGeros et al. 1969; Rey et al. 1989), and apart from carbonate, some domains also include absorption from other bands (e.g., $\mathrm{CH}$, $\mathrm{CN}, \mathrm{COO}-, \mathrm{NH}$ ) that overlap with $\mathrm{CO}_{3}{ }^{2-}$ (Elliott 1964; Termine et al. 1973) and hinder further interpretation.

\section{Collagen preservation}

Collagen preservation displays within-site variations, ranging from 0.86 to $12.07 \mathrm{wt} . \%$ (mean $=6.73)$ in human specimens, and between 1.90 and 13.23 wt.\% (mean = 8.35) in animal bones (Table 1). A $t$ test indicated no statistically significant differences between the two groups in collagen wt.\% $(t(22)=$ $48.000, p=0.352$ ), although the number of samples was small (human bones $n=17$; animal bones $n=7$ ). Further, a one-way ANOVA test was also performed to determine whether the three different diagenetic pathways display statistically significant differences in collagen yields. The collagen yields 

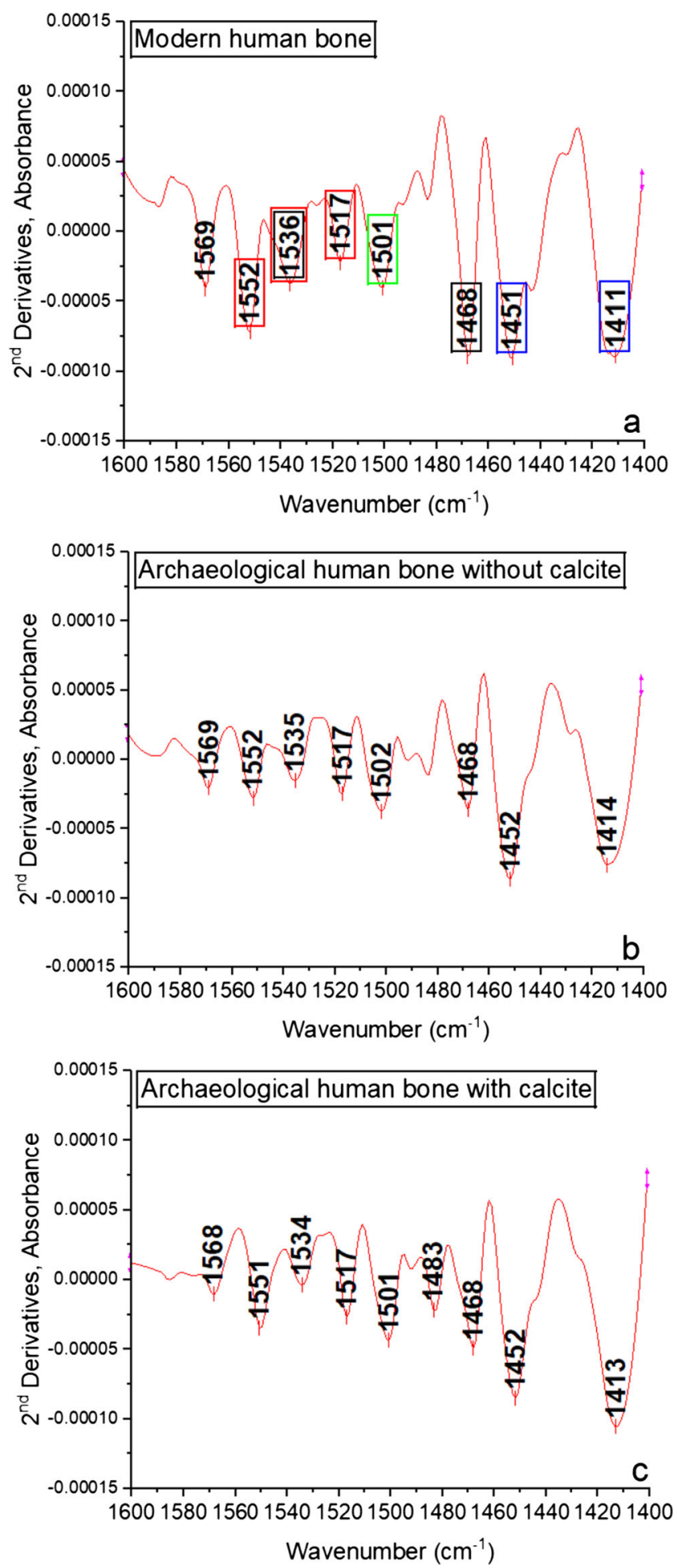

Fig. 8 The complex 2nd derivative spectra of the $\nu_{3}$ carbonate mode (c. $1400-1600 \mathrm{~cm}^{-1}$ ) of modern human bone (a) and two archaeological human bones with $\mathrm{C} / \mathrm{P}=0.16$ but different calcite amounts (b KAS13; c KAS3) Black boxes highlight the possible type A carbonate components; blue boxes highlight the possible type B carbonate components; green box highlights a possible non-apatitic (labile) carbonate component; red boxes highlight the possible organic (amide II) components (Termine et al. 1973; Rey et al. 1989; Fleet and Liu 2004; Brangule and Gross 2015; Madupalli et al. 2017) (wt.\%) are statistically significant different between those three groups $(F(2)=6.471, p=0.008)$ as the diagenetic pathway 1 displays very poor collagen preservation (collagen wt. $\%=1.8 \pm 1.06$ ) compared with the other two diagenetic pathways (diagenetic pathway 1 vs. pathway 2: $p=0.019$; diagenetic pathway 1 vs. pathway $3: p=0.007$ ). The diagenetic pathway 2 mean collagen yield is $7.56 \pm 3.69$, and the diagenetic pathway 3 displays slightly higher mean collagen yield $(8.32 \pm 3.08)$ which are not statistically significantly different $(p=0.873)$.

Collagen $\mathrm{C} / \mathrm{N}$ ratios were used for quality assessment with values ranging from 3.19 to 3.99 (Table 1). Values similar to modern bone (i.e., 2.9 to 3.6) are considered representative of good-quality collagen, while higher $\mathrm{C} / \mathrm{N}$ ratios are related to diagenesis (DeNiro 1985; DeNiro and Weiner 1988; Ambrose 1990; Tuross 2002). Only three human specimens with diagenetic pathway 1 characteristics (KAS1, KAS7, KAS15) exhibit $\mathrm{C} / \mathrm{N}>3.6$ (Table 1). These samples also show calcite uptake, while KAS7 and KAS15 have collagen yields below the $1 \mathrm{wt} . \%$ that is currently considered the threshold for isotopic and/or radiocarbon dating studies (van Klinken 1999; Dobberstein et al. 2009; Brock et al. 2010, 2012). Thus, collagen retained within these bones may not purely reflect original biochemical signals.

Apart from the uptake of exogenous carbon, post-mortem alterations in the collagen carbon and nitrogen contents are affected by microbial attack and hydrolysis (Ambrose 1990; Hedges et al. 1995; Balzer et al. 1997; Tuross 2002; TurnerWalker 2008; Harbeck and Grupe 2009). Hydrophobic amino acids may have been hydrolyzed during wet periods in Kastrouli, whereas a possible microbial attack to the amino acids with a higher number of carbons may have also occurred in samples displaying MFD, altering the $\mathrm{C} / \mathrm{N}$ ratio (Masters 1987; Grupe 1995; Balzer et al. 1997; Turban-Just and Schramm 1998; Tuross 2002; Harbeck and Grupe 2009).

While bone may preserve its microstructure without preserving its collagen content due to hydrolysis (Hedges et al. 1995; Collins et al. 2002), in this secondary Mycenaean burial poor histological preservation is often accompanied by good collagen preservation (Table 1). This observation shows that many bones can still retain appreciable quantities of protein even after extensive histological alterations (Hedges et al. 1995) and highlights the limitations of GHI's use as a collagen indicator.

The interaction between the mineral and organic fractions of bone is generally considered strong during diagenesis (Person et al. 1995, 1996; Nielsen-Marsh et al. 2000). This view is based on the fact that the orientation and size of BAp crystals in vivo are controlled by the fibril structure and organization as they are situated between (inter-fibrillar spaces) or on the surfaces (intra-fibrillar spaces) of collagen fibrils (Weiner and Traub 1986; Weiner and Price 1986; Boskey 2003). However, in Kastrouli only a moderate correlation 
between crystallinity (IRSF) and collagen content $\left(R^{2}=0.44\right)$ is observed (Fig. 9a), something that has also been reported in past studies (Lebon et al. 2010; Weiner and Bar-Yosef 1990; Hedges et al. 1995). Thus, our data suggest that bioapatite recrystallization is possible even in the presence of reasonable amounts of collagen in bone (Reiche et al. 2003), while within the same burial environment the volume of bone matrix that is filled with collagen in vivo can be replaced by BAp crystals of increased size (Trueman et al. 2008b; Susini et al. 1988; Pfretzschner 2004).

The Am/P ratio shows a strong correlation $\left(R^{2}=0.74\right)$ with collagen wt.\% (Fig. 9b) which highlights the potential of Am/ $\mathrm{P}$ as collagen predictor for rapid screening. The application of the $\mathrm{Am} / \mathrm{P}$ ratio as a quantitative approach to estimate collagen yields using the Lebon et al. (2016) equation (i.e., collagen wt. $\%=113.13 \mathrm{Am} / \mathrm{P}+1.69$ ), however, displays a mean offset of $-0.94 \pm 1.37 \%$ in Kastrouli. The relative phosphate content can lead to poor agreement of collagen estimates with collagen yields in some specimens (e.g., KAS8, KAS9), while overtones related to $\mathrm{O}-\mathrm{H}$ stretching vibrations at 1640 $1660 \mathrm{~cm}^{-1}$ (structural water) can also lead to increased values (Trueman et al. 2008a; Lebon et al. 2016). Further, any differences in collagen and FTIR protocols can also have significant effects on the collagen content estimates (e.g., Sealy et al. 2014; Kontopoulos et al. 2018).

Additional qualitative evidence can be obtained through the $2^{\text {nd }}$ derivative analysis of the amide I band that shows a gradual decrease of the $1632 \mathrm{~cm}^{-1}, 1640 \mathrm{~cm}^{-1}$, and $1650 \mathrm{~cm}^{-1}$ components assigned to the polyproline II helix (Lazarev et al.
1985) with decreasing collagen yields in archaeological bone (Fig. 10). Cleavage of collagen cross-linking as seen from a decrease of the $1660 \mathrm{~cm}^{-1}$ and $1695 \mathrm{~cm}^{-1}$ components (Fig. 10) (Paschalis et al. 2001) has led to a loss of the threedimensional structure and breaking of the polypeptides into smaller peptides during hydrolysis (Collins et al. 1995, 2002; Shoulders and Raines 2009; Adzhubei et al. 2013). High average temperatures have also significantly affected the rate of collagen degradation in Kastrouli bones as higher temperatures accelerate collagen loss resulting in the thermal age at Kastrouli (Fig. 5) estimated to be approximately three times the real age (Collins et al. 2002; Kendall et al. 2018).

\section{Summary}

Skeletal remains in this Mycenaean secondary burial have been seriously affected by diagenesis. Post-mortem modifications observed in microstructure, bioapatite, and collagen are characteristic of burial environments with groundwater fluctuation and high average temperatures. Withinsite differences may be related to different microenvironment conditions (e.g., groundwater, contact with limestone bedrock). However, as all bones were found within $30 \mathrm{~cm}$ of sediment, these bones have possibly experienced different early taphonomic histories. The death history and the effects of various factors (e.g., season of death, clothing, burial location) on bone degradation are often overlooked in archaeology due to lack of relevant information. In
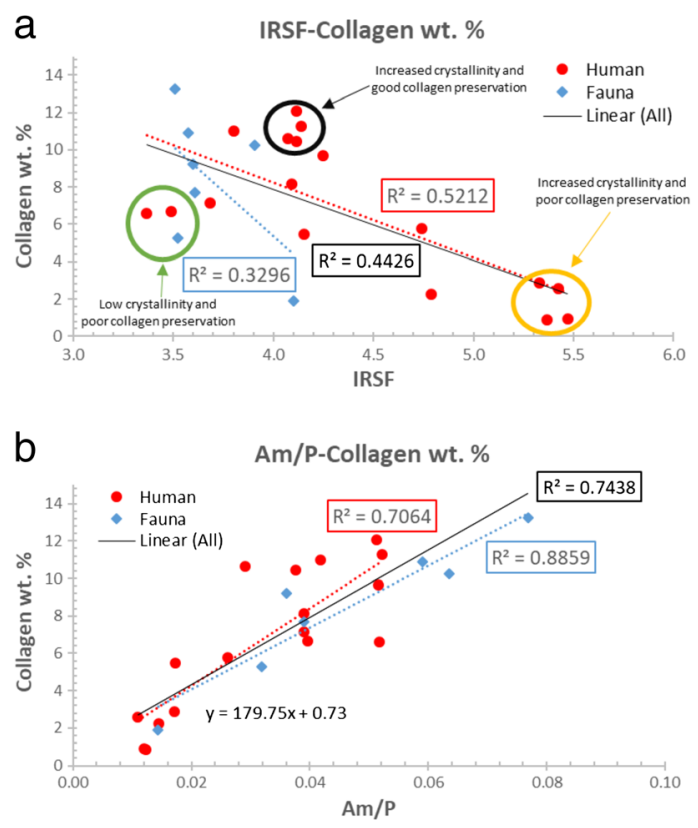

Fig. 9 a The moderate relationship between IRSF-collagen wt.\%. Note the group characterized by high IRSF and low collagen yields (yellow circle), a second group that displays low IRSF and low collagen yields (green circle) and a third group showing increased crystallinity and high collagen yields (black circle), indicative of the different combination of diagenetic pathways followed by these specimens. b The reliability of $\mathrm{Am} / \mathrm{P}$ for predicting collagen content in archaeological bone. 

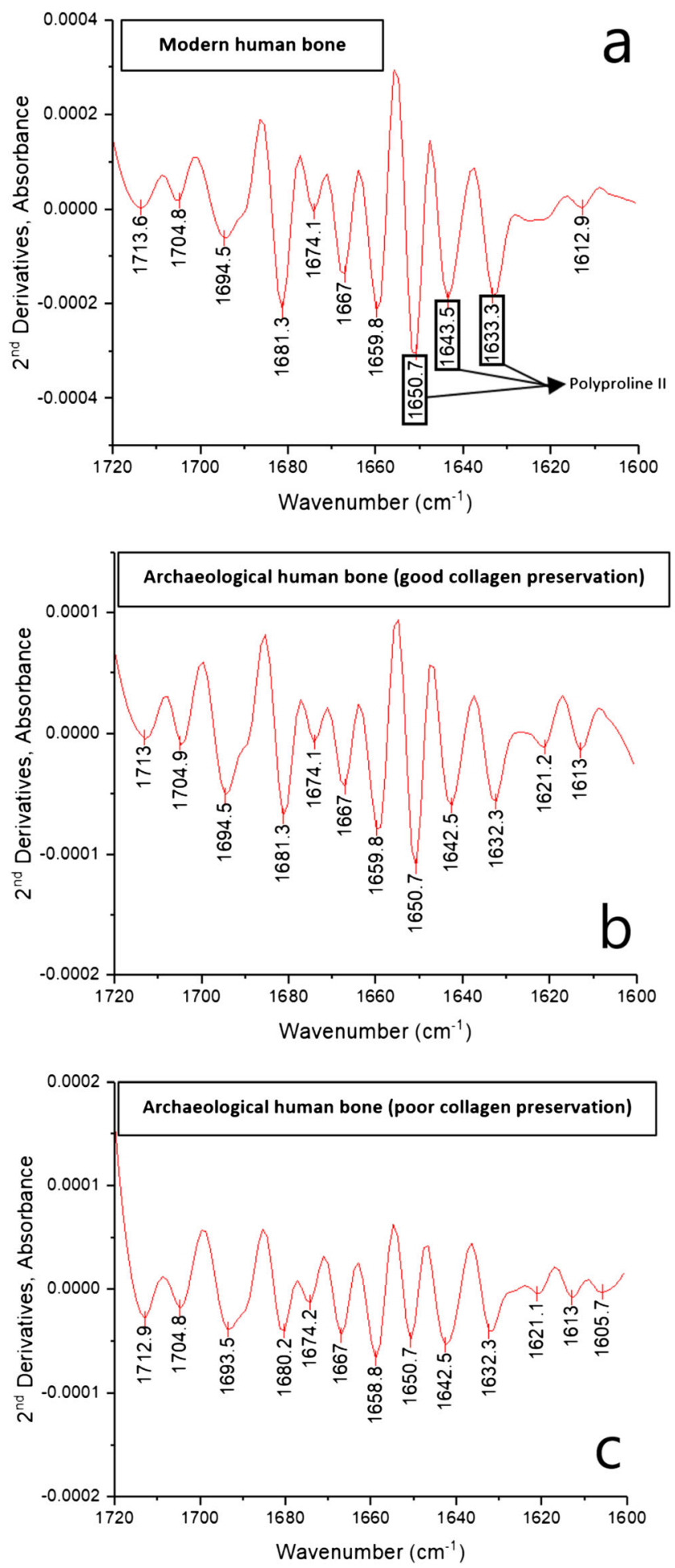

Fig. 10 a Second derivative spectra of the amide I band (c. 1600$1700 \mathrm{~cm}^{-1}$ ) showing the disappearance of amide I components (black boxes) that accompany loss of collagen in archaeological bone (b KAS8; c KAS7)

secondary burials, the skeletal remains of a body (either exposed on the ground surface, interred in a coffin or buried directly into the soil) are retrieved and relocated once the soft tissue has decayed to some degree or excarnated. Therefore, future analyses may help understand the sequence of these alterations and shed light on past funerary practices such as disarticulation and primary and secondary treatments.

\section{Key points}

\section{Histology}

1. Three distinct diagenetic pathways were identified based on the presence/absence of microscopic focal destruction, microcracking and orange/brown staining of bone tissue.

2. Generalized destruction was observed in all human femora and animal bones.

3. The two human petrous bones show moderate histological preservation, and the endosteal tissue that surrounds the cochlea and semicircular canal areas is unexpectedly more degraded than the other tissue zones.

\section{Bioapatite}

1. The seasonal and sporadic flow of rainwater through the bones which were situated near the ground surface (depth c. $1 \mathrm{~m}$ ) likely led to the dissolution and recrystallization of bioapatite crystals (increased crystallinity, loss of carbonate, calcite uptake).

2. The two human petrous bones show poor bioapatite preservation with high crystallinity and loss of carbonate content.

3. $2^{\text {nd }}$ derivative analysis of bone mid-IR spectra provides useful information on bioapatite carbonate environments ( $\nu_{2}$ carbonate band at c. $850-900 \mathrm{~cm}^{-1}$ and $\nu_{3}$ carbonate mode at c. $1400-1600 \mathrm{~cm}^{-1}$ ) and how they interact with calcite during recrystallization.

\section{Collagen}

1. Collagen yields do not show any strong correlation with crystallinity suggesting that bioapatite recrystallization is possible even in the presence of reasonable amounts of collagen in bone.

2. The two human petrous bones display good collagen preservation, with about half of the initial collagen content surviving.

3. The Am/P ratio can potentially provide valuable information on the relative amount of collagen in bone, while GHI's use as collagen indicator is limited.

4. $2^{\text {nd }}$ derivative analysis of the amide I band (c. 1600 $1700 \mathrm{~cm}^{-1}$ ) of bone mid-IR spectra can provide useful information on the components lost (e.g., polyproline II, cross-links) during collagen degradation. 
Acknowledgments Our warmest thanks go to Athanasios Sideris (fieldwork), Andreas Bertsatos, and Marilena Chovalopoulou (osteological analysis and sampling). We are grateful to Prof. Peter Zioupos for the two modern human samples (NHS REC approval 10/H0107/14) which were used as references with the kind permission of the Department of Biology Ethics Committee (BEC) of the University of York. IL thanks the Ministry of Culture (Greece) and the Ephorate of Antiquities of Phokis (Delphi) for the permit. IK would like to thank Onassis Foundation (Grant No. F ZL 047-1/2015-2016), Leventis Foundation and the Greek Archaeological Committee UK (GACUK). KP thanks the Leverhulme Trust (PLP-2012-116) and MJC thanks the DNRF for the award of a Niels Bohr Professorship.

Open Access This article is distributed under the terms of the Creative Commons Attribution 4.0 International License (http:// creativecommons.org/licenses/by/4.0/), which permits unrestricted use, distribution, and reproduction in any medium, provided you give appropriate credit to the original author(s) and the source, provide a link to the Creative Commons license, and indicate if changes were made.

\section{References}

Adams B, Byrd J (2014) Commingled human remains: methods in recovery, analysis and identification. Elsevier Science \& Technology, San Diego United States

Adzhubei AA, Sternberg MJE, Makarov AA (2013) Polyproline-II helix in proteins: structure and function. J Mol Biol 425:2100-2132. https://doi.org/10.1016/j.jmb.2013.03.018

Ajie HO, Hauschka PV, Kaplan IR (1991) Comparison of bone collagen and osteocalcin for determination of radiocarbon ages and paleodietary reconstruction I. Earth Planet Sci Lett 107:380-388

Ambrose SH (1991) Effects of diet, climate and physiology on nitrogen isotope abundances in terrestrial foodwebs. J Archaeol Sci 18:293317

Ambrose SH (1990) Preparation and characterization of bone and tooth collagen for isotopic analysis. J Archaeol Sci 17:431-451. https:// doi.org/10.1016/0305-4403(90)90007-r

Asara JM, Schweitzer MH, Freimark LM, Phillips M, Cantley LC (2007) Protein sequences from mastodon and Tyrannosaurus rex revealed by mass spectrometry. Science 316:280-285. https://doi.org/10. 1126/science. 1137614

Asscher Y, Regev L, Weiner S, Boaretto E (2011) Atomic disorder in fossil tooth and bone mineral: an FTIR study using the grinding curve method. Archeosciences:135-141. https://doi.org/10.4000/ archeosciences. 3062

Assis S, Santos A, Keenleyside A (2016) Paleohistology and the study of human remains: past, present and future approaches. Rev Arg Antrop Biol 18:1-17. https://doi.org/10.17139/raab.2016.0018.02. 02

Balzer A, Gleixner G, Grupe G et al (1997) In vitro decomposition of bone collagen by soil bacteria: the implications for stable isotope analysis in archaeometry. Archaeometry 39:415-429

Baxter JD, Biltz RM, Pellegrino ED (1966) The physical state of bone carbonate. A comparative infra-red study in several mineralized tissues. Yale J Biol Med 38:456-470

Bell L (2012) Histotaphonomy. In: Bone histology. CRC Press, pp 241251

Bell LS (1990) Palaeopathology and diagenesis: an SEM evaluation of structural changes using backscattered electron imaging. J Archaeol Sci 17:85-102. https://doi.org/10.1016/0305-4403(90)90016-X

Berna F, Matthews A, Weiner S (2004) Solubilities of bone mineral from archaeological sites: the recrystalization window. J Archaeol Sci 31: $867-882$
Booth TJ, Madgwick R (2016) New evidence for diverse secondary burial practices in Iron age Britain: a histological case study. J Archaeol Sci 67:14-24. https://doi.org/10.1016/j.jas.2016.01.010

Boskey AL (2003) Bone mineral crystal size. Osteoporos Int 14(Suppl 5): S16-S20; discussion S20-1. https://doi.org/10.1007/s00198-003$1468-2$

Brangule A, Gross KA (2015) Importance of FTIR spectra deconvolution for the analysis of amorphous calcium phosphates. IOP Conf Ser: Mater Sci Eng 77:012027. https://doi.org/10.1088/1757-899X/77/1/ 012027

Brock F, Higham T, Ramsey CB (2010) Pre-screening techniques for identification of samples suitable for radiocarbon dating of poorly preserved bones. J Archaeol Sci 37:855-865. https://doi.org/10. 1016/j.jas.2009.11.015

Brock F, Wood R, Higham TFG, Ditchfield P, Bayliss A, Ramsey CB (2012) Reliability of nitrogen content $(\% \mathrm{~N})$ and carbon:nitrogen atomic ratios $(\mathrm{C}: \mathrm{N})$ as indicators of collagen preservation suitable for radiocarbon dating. Radiocarbon 54:879-886. https://doi.org/10. 1017/S0033822200047524

Buckley M, Collins M, Thomas-Oates J (2009) Species identification by analysis of bone collagen using matrix-assisted laser desorption/ ionisation time-of-flight mass spectrometry. Rapid Commun Mass Spectrom 23:3843-3854. https://doi.org/10.1002/rcm.4316

Caruso V, Cummaudo M, Maderna E, Cappella A, Caudullo G, Scarpulla V, Cattaneo C (2018) A comparative analysis of microscopic alterations in modern and ancient undecalcified and decalcified dry bones. Am J Phys Anthropol 165:363-369. https://doi.org/10. 1002/ajpa.23348

Cattaneo C, DiMartino S, Scali S, Craig OE, Grandi M, Sokol RJ (1999) Determining the human origin of fragments of burnt bone: a comparative study of histological, immunological and DNA techniques. Forensic Sci Int 102:181-191

Chadefaux C, Le Hô A-S, Bellot-Gurlet L, Reiche I (2009) Curve-fitting micro-ATR-FTIR studies of the amide I and II bands of type I collagen in archaeological bone materials. e-PS 6:129-137

Chovalopoulou M-E, Bertsatos A, Manolis SK (2017) Identification of skeletal remains from a Mycenaean burial in Kastrouli-Desfina. Greece Mediter Archaeol Archaeom 17:265-269. https://doi.org/ 10.5281/zenodo.556353

Collins MJ, Galley P (1998) Towards an optimal method of archaeological collagen extraction: the influence of $\mathrm{pH}$ and grinding. Anc Biomol 2:209-223

Collins MJ, CM N-M, Hiller J et al (2002) The survival of organic matter in bone: a review. Archaeometry 44:383-394. https://doi.org/10. 1111/1475-4754.t01-1-00071

Collins MJ, Penkman KEH, Rohland N, Shapiro B, Dobberstein RC, Ritz-Timme S, Hofreiter M (2009) Is amino acid racemization a useful tool for screening for ancient DNA in bone? Proc Biol Sci 276:2971-2977. https://doi.org/10.1098/rspb.2009.0563

Collins MJ, Riley MS, Child AM, Turner-Walker G (1995) A basic mathematical simulation of the chemical degradation of ancient collagen. J Archaeol Sci 22:175-183. https://doi.org/10.1006/jasc.1995.0019

Collins MJ, Waite ER, van Duin ACT, Eglinton G (1999) Predicting protein decomposition: the case of aspartic-acid racemization kinetics. Philos Trans R Soc Lond Ser B Biol Sci 354:51-64

Cuijpers AGFM (2006) Histological identification of bone fragments in archaeology: telling humans apart from horses and cattle. Int $\mathrm{J}$ Osteoarchaeol 16:465-480. https://doi.org/10.1002/oa.848

De Boer HH, Van der Merwe AE, Maat GJR (2013) The diagnostic value of microscopy in dry bone palaeopathology: a review. Int J Paleopathol 3:113-121. https://doi.org/10.1016/j.ijpp.2013.03.004

DeNiro MJ (1985) Postmortem preservation and alteration of in vivo bone collagen isotope ratios in relation to palaeodietary reconstruction. Nature 317:806-809. https://doi.org/10.1038/317806a0T

DeNiro MJ, Weiner S (1988) Chemical, enzymatic and spectroscopic characterization of "collagen" and other organic fractions from 
prehistoric bones. Geochim Cosmochim Acta 52:2197-2206. https://doi.org/10.1016/0016-7037(88)90122-6

Dobberstein RC, Collins M, Craig O et al (2009) Archaeological collagen: why worry about collagen diagenesis. Archaeol Anthropol Sci $1: 31-42$

Doden E, Halves R (1984) On the functional morphology of the human petrous bone. Am J Anat 169:451-462. https://doi.org/10.1002/aja. 1001690407

Dominguez VM, Crowder CM (2012) The utility of osteon shape and circularity for differentiating human and non-human Haversian bone. Am J Phys Anthropol 149:84-91. https://doi.org/10.1002/ ajpa.22097

Douka K, Slon V, Stringer C, Potts R, Hübner A, Meyer M, Spoor F, Pääbo S, Higham T (2017) Direct radiocarbon dating and DNA analysis of the Darra-i-Kur (Afghanistan) human temporal bone. J Hum Evol 107:86-93. https://doi.org/10.1016/j.jhevol.2017.03.003

Elliott JC (1964) The crystallographic structure of dental enamel and related apatites. $\mathrm{PhD}$ thesis, University of London, London, UK

Elliott JC, Holcomb DW, Young RA (1985) Infrared determination of the degree of substitution of hydroxyl by carbonate ions in human dental enamel. Calcif Tissue Int 37:372-375

Fernandez-Jalvo Y, Andrews P, Pesquero D et al (2010) Early bone diagenesis in temperate environments. Part I: surface features and histology. Palaeogeogr Palaeoclimatol Palaeoecol 288:62-81

Fernández-Jalvo Y, Pesquero MD, Tormo L (2016) Now a bone, then calcite. Palaeogeogr Palaeoclimatol Palaeoecol 444:60-70

Figueiredo MM, Gamelas JAF, Martins AG (2012) Characterization of bone and bone-based graft materials using FTIR spectroscopy. In: Theophanides T (ed) Infrared spectroscopy-life and biomedical sciences. IntechOpen, pp 315-338

Fleet ME (2009) Infrared spectra of carbonate apatites: v2-Region bands. Biomaterials 30:1473-1481. https://doi.org/10.1016/j.biomaterials. 2008.12.007

Fleet ME, Liu X (2004) Location of type B carbonate ion in type A-B carbonate apatite synthesized at high pressure. J Solid State Chem 177:3174-3182. https://doi.org/10.1016/j.jssc.2004.04.002

Fleet ME, Liu X (2005) Local structure of channel ions in carbonate apatite. Biomaterials 26:7548-7554. https://doi.org/10.1016/j. biomaterials.2005.05.025

Fleet ME, Liu X, King PL (2004) Accommodation of the carbonate ion in apatite: an FTIR and X-ray structure study of crystals synthesized at 2-4 GPa. Am Mineral 89:1422-1432. https://doi.org/10.2138/am2004-1009

Frisch T, Sørensen MS, Overgaard S, Bretlau P (2000) Estimation of volume referent bone turnover in the otic capsule after sequential point labeling. Ann Otol Rhinol Laryngol 109:33-39. https://doi. org/10.1177/000348940010900106

Gander W, von Matt U (1993) Smoothing filters. In: Gander W, Hřebíček $\mathrm{J}$ (eds) Solving problems in scientific computing using maple and Matlab®. Springer, Berlin, pp 121-139

Garland AN (1989) Microscopical analysis of fossil bone. Appl Geochem 4:215-229. https://doi.org/10.1016/0883-2927(89)90021-8

Grupe G (1995) Preservation of collagen in bone from dry, sandy soil. J Archaeol Sci 22:193-199

Grupe G, Balzer A, Turban-Just S (2002) Modeling protein diagenesis in ancient bone: towards a validation of stable isotope data. In: Ambrose SH, Katzenberg MA (eds) Biogeochemical approaches to paleodietary analysis. Springer US, Boston, MA, pp 173-187

Gueta R, Natan A, Addadi L, Weiner S, Refson K, Kronik L (2007) Local atomic order and infrared spectra of biogenic calcite. Angew Chem Int Ed Eng 46:291-294. https://doi.org/10.1002/anie.200603327

Hackett CJ (1981) Microscopical focal destruction (tunnels) in exhumed human bones. Med Sci Law 21:243-265. https://doi.org/10.1177/ 002580248102100403
Hanson M, Cain CR (2007) Examining histology to identify burned bone. J Archaeol Sci 34:1902-1913. https://doi.org/10.1016/j.jas.2007.01. 009

Harbeck M, Grupe G (2009) Experimental chemical degradation compared to natural diagenetic alteration of collagen: implications for collagen quality indicators for stable isotope analysis. Archaeol Anthropol Sci 1:43-57. https://doi.org/10.1007/s12520-009-0004-5

Hedges REM (2003) On bone collagen - apatite-carbonate isotopic relationships. Int J Osteoarchaeol 13:66-79. https://doi.org/10.1002/oa. 660

Hedges REM (2002) Bone diagenesis: an overview of processes. Archaeometry 44:319-328. https://doi.org/10.1111/1475-4754. 00064

Hedges REM, Millard AR (1995) Bones and groundwater: towards the modelling of diagenetic processes. J Archaeol Sci 22:155-164. https://doi.org/10.1006/jasc.1995.0017

Hedges REM, Millard AR, Pike AWG (1995) Measurements and relationships of diagenetic alteration of bone from three archaeological sites. J Archaeol Sci 22:201-209. https://doi.org/10.1006/jasc.1995. 0022

High K, Milner N, Panter I, Penkman KEH (2015) Apatite for destruction: investigating bone degradation due to high acidity at Star Carr. J Archaeol Sci 59:159-168. https://doi.org/10.1016/j.jas.2015.04. 001

Hollund HI, Jans MME, Collins MJ, Kars H, Joosten I, Kars SM (2012) What happened here? Bone histology as a tool in decoding the postmortem histories of archaeological bone from Castricum, the Netherlands. Int J Osteoarchaeol 22:537-548. https://doi.org/10. 1002/oa.1273

Hunt JM, Wisherd MP, Bonham LC (1950) Infrared absorption spectra of minerals and other inorganic compounds. Anal Chem 22:14781497. https://doi.org/10.1021/ac60048a006

Jackes M, Sherburne R, Lubell D, Barker C, Wayman M (2001) Destruction of microstructure in archaeological bone: a case study from Portugal. Int J Osteoarchaeol 11:415-432

Jeffery N, Spoor F (2004) Prenatal growth and development of the modern human labyrinth. J Anat 204:71-92. https://doi.org/10.1111/j. 1469-7580.2004.00250.x

Jones OA (2014) The study of secondary burial in Mycenaean mortuary traditions: a new approach to the evidence. Tijdschrift voor Mediterrane Archeologie 26:8-13

Katić V, Vujicić G, Ivanković D et al (1991) Distribution of structural and trace elements in human temporal bone. Biol Trace Elem Res 29: $35-43$

Kendall C, Eriksen AMH, Kontopoulos I, Collins MJ, Turner-Walker G (2018) Diagenesis of archaeological bone and tooth. Palaeogeogr Palaeoclimatol Palaeoecol 491:21-37. https://doi.org/10.1016/j. palaeo.2017.11.041

King CL, Tayles N, Gordon KC (2011) Re-examining the chemical evaluation of diagenesis in human bone apatite. J Archaeol Sci 38:2222 2230. https://doi.org/10.1016/j.jas.2011.03.023

Kontopoulos I, Nystrom P, White L (2016) Experimental taphonomy: post-mortem microstructural modifications in sus scrofa domesticus bone. Forensic Sci Int 266:320-328. https://doi.org/10.1016/j. forsciint.2016.06.024

Kontopoulos I, Presslee S, Penkman K, Collins MJ (2018) Preparation of bone powder for FTIR-ATR analysis: the particle size effect. Vib Spectrosc 99:167-177. https://doi.org/10.1016/j.vibspec.2018.09. 004

Koon HEC, Nicholson RA, Collins MJ (2003) A practical approach to the identification of low temperature heated bone using TEM. J Archaeol Sci 30:1393-1399. https://doi.org/10.1016/S03054403(03)00034-7

Koon HEC, O'Connor TP, Collins MJ (2010) Sorting the butchered from the boiled. J Archaeol Sci 37:62-69. https://doi.org/10.1016/j.jas. 2009.08.015 
Kus S, Marczenko Z, Obarski N (1996) Derivative UV-VIS spectrophotometry in analytical chemistry. Chern Anal (Warsaw) 41:899

Lazarev YA, Grishkovsky BA, Khromova TB (1985) Amide I band of IR spectrum and structure of collagen and related polypeptides. Biopolymers 24:1449-1478. https://doi.org/10.1002/bip. 360240804

Lebon M, Reiche I, Bahain J-J, Chadefaux C, Moigne AM, Fröhlich F, Sémah F, Schwarcz HP, Falguères C (2010) New parameters for the characterization of diagenetic alterations and heat-induced changes of fossil bone mineral using Fourier transform infrared spectrometry. J Archaeol Sci 37:2265-2276. https://doi.org/10.1016/j.jas.2010.03. 024

Lebon M, Reiche I, Gallet X, Bellot-Gurlet L, Zazzo A (2016) Rapid quantification of bone collagen content by ATR-FTIR spectroscopy. Radiocarbon 58:131-145. https://doi.org/10.1017/RDC.2015.11

Lee-Thorp JA, van der Merwe NJ (1991) Aspects of the chemistry of modern and fossil biological apatites. J Archaeol Sci 18:343-354. https://doi.org/10.1016/0305-4403(91)90070-6

LeGeros RZ (1965) Effect of carbonate on the lattice parameters of apatite. Nature 206:403-404. https://doi.org/10.1038/206403a0

LeGeros RZ, Trautz OR, Klein E, LeGeros JP (1969) Two types of carbonate substitution in the apatite structure. Experientia 25:5-7. https://doi.org/10.1007/BF01903856

LeGeros RZ, Trautz OR, LeGeros JP et al (1967) Apatite crystallites: effects of carbonate on morphology. Science 155:1409-1411. https://doi.org/10.1126/science.155.3768.1409

Liritzis I, Jin Z, Fan A, Sideris A (2016) Late Helladic and later reuse phases of Kastrouli settlement (Greece): preliminary dating results. Mediter Archaeol Archaeom 16:245-250. https://doi.org/10.5281/ zenodo. 163775

Liritzis I, Polymeris GS, Vafiadou A, Sideris A, Levy TE (2019) Luminescence dating of stone wall, tomb and ceramics of Kastrouli (Phokis, Greece) late Helladic settlement: case study. J Cult Herit 35:76-85

Longin R (1971) New method of collagen extraction for radiocarbon dating. Nature 230:241-242

Madupalli H, Pavan B, Tecklenburg MMJ (2017) Carbonate substitution in the mineral component of bone: discriminating the structural changes, simultaneously imposed by carbonate in a and B sites of apatite. J Solid State Chem 255:27-35. https://doi.org/10.1016/j. jssc.2017.07.025

Mark H, Workman J Jr (2003) Derivatives in spectroscopy: part IIIcomputing the derivative. Spectroscopy 18:106-111

Masters PM (1987) Preferential preservation of noncollagenous protein during bone diagenesis: implications for chronometric and stable isotopic measurements. Geochim Cosmochim Acta 51:3209-3214. https://doi.org/10.1016/0016-7037(87)90129-3

Maurer A-F, Person A, Tütken T, Amblard-Pison S, Ségalen L (2014) Bone diagenesis in arid environments: an intra-skeletal approach. Palaeogeogr Palaeoclimatol Palaeoecol 416:17-29. https://doi.org/ 10.1016/j.palaeo.2014.08.020

Millard AR (2001) Deterioration of bone. In: Brothwell DR, Pollard AM (eds) Handbook of archaeological sciences. Wiley, pp 633-643

Moustris A, Petrou J (2019) Weather forecast for Greece. In: meteo.grWeather forecast for Greece. http://www.meteo.gr/. Accessed 1 Mar 2019

Moutafi I, Voutsaki S (2016) Commingled burials and shifting notions of the self at the onset of the Mycenaean era (1700-1500BCE): the case of the Ayios Vasilios North Cemetery, Laconia. J Archaeol Sci Rep 10:780-790. https://doi.org/10.1016/j.jasrep.2016.05.037

Mulhern DM, Ubelaker DH (2001) Differences in osteon banding between human and nonhuman bone. J Forensic Sci 46:220-222

Nielsen-Marsh C, Gernaey A, Turner-Walker G, et al (2000) The chemical degradation of bone. In: Cox M, Mays S (eds) Human osteology: in archaeology and forensic science. Cambridge University Press, pp 439-454
Nielsen-Marsh CM, Hedges REM (2000a) Patterns of diagenesis in bone I: the effects of site environments. J Archaeol Sci 27:1139-1150. https://doi.org/10.1006/jasc.1999.0537

Nielsen-Marsh CM, Hedges REM (2000b) Patterns of diagenesis in bone II: effects of acetic acid treatment and the removal of diagenetic $\mathrm{CO}_{3}{ }^{2-}$. J Archaeol Sci 27:1151-1159

Osterholtz AJ, Baustian KM, Martin DL (2013) Commingled and disarticulated human remains: working toward improved theory, method, and data. Springer, New York, NY

Paschalis EP, Verdelis K, Doty SB, Boskey AL, Mendelsohn R, Yamauchi M (2001) Spectroscopic characterization of collagen cross-links in bone. J Bone Miner Res 16:1821-1828. https://doi. org/10.1359/jbmr.2001.16.10.1821

Person A, Bocherens H, Mariotti A, Renard M (1996) Diagenetic evolution and experimental heating of bone phosphate. Palaeogeogr Palaeoclimatol Palaeoecol 126:135-149

Person A, Bocherens H, Saliege J-F et al (1995) Early diagenetic evolution of bone phosphate: an X-ray diffractometry analysis. J Archaeol Sci 22:211-221

Pesquero MD, Alcalá L, Bell LS, Fernández-Jalvo Y (2015) Bacterial origin of iron-rich microspheres in Miocene mammalian fossils. Palaeogeogr Palaeoclimatol Palaeoecol 420:27-34. https://doi.org/ 10.1016/j.palaeo.2014.12.006

Pfretzschner H-U (2004) Fossilization of Haversian bone in aquatic environments. C R Palevol 3:605-616. https://doi.org/10.1016/j.crpv. 2004.07.006

Pfretzschner H-U, Tütken T (2011) Rolling bones-taphonomy of Jurassic dinosaur bones inferred from diagenetic microcracks and mineral infillings. Palaeogeogr Palaeoclimatol Palaeoecol 310:117123. https://doi.org/10.1016/j.palaeo.2011.01.026

Piepenbrink H (1989) Examples of chemical changes during fossilisation. Appl Geochem 4:273-280. https://doi.org/10.1016/0883-2927(89) 90029-2

Piepenbrink H (1986) Two examples of biogenous dead bone decomposition and their consequences for taphonomic interpretation. $\mathrm{J}$ Archaeol Sci 13:417-430. https://doi.org/10.1016/0305-4403(86) 90012-9

Poinar HN, Höss M, Bada JL, Pääbo S (1996) Amino acid racemization and the preservation of ancient DNA. Science 272:864-866

Reiche I, Favre-Quattropani L, Vignaud C, Bocherens H, Charlet L, Menu M (2003) A multi-analytical study of bone diagenesis: the Neolithic site of Bercy (Paris, France). Meas Sci Technol 14: 1608-1619

Reiche I, Vignaud C, Menu M (2002) The crystallinity of ancient bone and dentine: new insights by transmission electron microscopy. Archaeometry 44:447-459. https://doi.org/10.1111/1475-4754. 00077

Rey C, Collins B, Goehl T, Dickson IR, Glimcher MJ (1989) The carbonate environment in bone mineral: a resolution-enhanced Fourier transform infrared spectroscopy study. Calcif Tissue Int 45:157-164

Rey C, Combes C (2014) What bridges mineral platelets of bone? Bonekey Rep 3:586. https://doi.org/10.1038/bonekey.2014.81

Rey C, Combes C, Drouet C, Sfihi H, Barroug A (2007) Physicochemical properties of nanocrystalline apatites: implications for biominerals and biomaterials. Mater Sci Eng C 27:198-205. https://doi.org/10.1016/j.msec.2006.05.015

Reznikov N, Shahar R, Weiner S (2014) Three-dimensional structure of human lamellar bone: the presence of two different materials and new insights into the hierarchical organization. Bone 59:93-104. https://doi.org/10.1016/j.bone.2013.10.023

Schafer RW (2011) What is a Savitzky-Golay filter? [lecture notes]. IEEE Signal Process Mag 28:111-117. https://doi.org/10.1109/MSP.2011. 941097

Schroeder S (2001) Secondary disposal of the dead: cross-cultural codes. World Cultures 12:77-93 
Sealy J, Johnson M, Richards M, Nehlich O (2014) Comparison of two methods of extracting bone collagen for stable carbon and nitrogen isotope analysis: comparing whole bone demineralization with gelatinization and ultrafiltration. J Archaeol Sci 47:64-69. https://doi. org/10.1016/j.jas.2014.04.011

Shoulders MD, Raines RT (2009) Collagen structure and stability. Annu Rev Biochem 78:929-958. https://doi.org/10.1146/annurev. biochem.77.032207.120833

Sideris A, Liritzis I, Liss B et al (2017) At-risk cultural heritage: new excavations and finds from the Mycenaean site of Kastrouli, Phokis, Greece. Mediter Archaeol Archaeom 17:271-285. https://doi.org/ 10.5281/zenodo. 163772

Sponheimer M, Lee-Thorp JA (1999) Alteration of enamel carbonate environments during fossilization. J Archaeol Sci 26:143-150. https://doi.org/10.1006/jasc.1998.0293

Stathopoulou ET, Psycharis V, Chryssikos GD, Gionis V, Theodorou G (2008) Bone diagenesis: new data from infrared spectroscopy and X-ray diffraction. Palaeogeogr Palaeoclimatol Palaeoecol 266:168 174. https://doi.org/10.1016/j.palaeo.2008.03.022

Stiner MC, Kuhn SL, Weiner S, Bar-Yosef O (1995) Differential burning, recrystallization, and fragmentation of archaeological bone. $\mathrm{J}$ Archaeol Sci 22:223-237

Stout SD, Teitelbaum SL (1976) Histological analysis of undecalcified thin sections of archeological bone. Am J Phys Anthropol 44:263269. https://doi.org/10.1002/ajpa.1330440208

Susini A, Baud CA, Lacotte D (1988) Bone apatite crystals alterations in Neolithic skeletons and their relations to burial practices and soil weathering. Rivista di antropologia 66:35-38

Talsky G (1994) Derivative spectrophotometry: low and higher order. Wiley-VCH

Termine JD, Eanes ED, Greenfield DJ, Nylen MU, Harper RA (1973) Hydrazine-deproteinated bone mineral. Calcif Tissue Res 12:73-90. https://doi.org/10.1007/BF02013723

Traub W, Arad T, Weiner S (1992) Origin of mineral crystal growth in collagen fibrils. Matrix 12:251-255. https://doi.org/10.1016/S09348832(11)80076-4

Trueman CN (2013) Chemical taphonomy of biomineralized tissues. Palaeontology 56:475-486. https://doi.org/10.1111/pala.12041

Trueman CNG, Behrensmeyer AK, Tuross N, Weiner S (2004) Mineralogical and compositional changes in bones exposed on soil surfaces in Amboseli National Park, Kenya: diagenetic mechanisms and the role of sediment pore fluids. J Archaeol Sci 31:721-739. https://doi.org/10.1016/j.jas.2003.11.003

Trueman CN, Privat K, Field J (2008a) Why do crystallinity values fail to predict the extent of diagenetic alteration of bone mineral? Palaeogeogr Palaeoclimatol Palaeoecol 266:160-167. https://doi. org/10.1016/j.palaeo.2008.03.038

Trueman CN, Palmer MR, Field J, Privat K, Ludgate N, Chavagnac V, Eberth DA, Cifelli R, Rogers RR (2008b) Comparing rates of recrystallisation and the potential for preservation of biomolecules from the distribution of trace elements in fossil bones. C R Palevol 7: 145-158. https://doi.org/10.1016/j.crpv.2008.02.006

Turban-Just S, Schramm S (1998) Stable carbon and nitrogen isotope ratios of individual amino acids give new insights into bone collagen degradation. Bull Soc Geol Fr 169:109-114

Turner-Walker G (2008) The chemical and microbial degradation of bones and teeth. In: Pinhasi R, Mays S (eds) Advances in human palaeopathology. Wiley, West Sussex, pp 1-29

Turner-Walker G, Jans M (2008) Reconstructing taphonomic histories using histological analysis. Palaeogeogr Palaeoclimatol Palaeoecol 266:227-235. https://doi.org/10.1016/j.palaeo.2008.03.024

Tuross N (2002) Alterations in fossil collagen. Archaeometry 44:427434. https://doi.org/10.1111/1475-4754.00075

van Doorn NL, Wilson J, Hollund H, Soressi M, Collins MJ (2012) Sitespecific deamidation of glutamine: a new marker of bone collagen deterioration. Rapid Commun Mass Spectrom 26:2319-2327. https://doi.org/10.1002/rcm.6351

van Klinken GJ (1999) Bone collagen quality indicators for palaeodietary and radiocarbon measurements. J Archaeol Sci 26:687-695. https:// doi.org/10.1006/jasc. 1998.0385

Weiner S, Bar-Yosef O (1990) States of preservation of bones from prehistoric sites in the Near East: a survey. J Archaeol Sci 17:187-196. https://doi.org/10.1016/0305-4403(90)90058-D

Weiner S, Price PA (1986) Disaggregation of bone into crystals. Calcif Tissue Int 39:365-375

Weiner S, Traub W (1986) Organization of hydroxyapatite crystals within collagen fibrils. FEBS Lett 206:262-266

White L, Booth TJ (2014) The origin of bacteria responsible for bioerosion to the internal bone microstructure: results from experimentally-deposited pig carcasses. Forensic Sci Int 239:92102. https://doi.org/10.1016/j.forsciint.2014.03.024

White WB (1974) The carbonate minerals. In: Farmer VC (ed) The infrared spectra of minerals. Mineralogical Society of Great Britain and Ireland, pp 227-284

Wopenka B, Pasteris JD (2005) A mineralogical perspective on the apatite in bone. Mater Sci Eng C 25:131-143. https://doi.org/10.1016/j. msec.2005.01.008

Wright LE, Schwarcz HP (1996) Infrared and isotopic evidence for diagenesis of bone apatite at Dos Pilas, Guatemala: palaeodietary implications. J Archaeol Sci 23:933-944

Publisher's note Springer Nature remains neutral with regard to jurisdictional claims in published maps and institutional affiliations. 